\title{
CEREMONIAL INCA PROVINCIAL: EL ASENTAMIENTO DE SAGUARA (CUENCA DE CAMARONES) ${ }^{1}$
}

\author{
PROVINCIAL INCA CEREMONIAL: THE SAGUARA SETTLEMENT \\ (CAMARONES BASIN)
}

Virgilio Schiappacasse F. ${ }^{\dagger}$ y Hans Niemeyer F**

\begin{abstract}
Presentamos un yacimiento inca situado en la sierra de la cuenca de Camarones, del extremo norte de Chile. Después de analizar las características arquitectónicas y los restos culturales de los diferentes sectores que componen el sitio, proponemos atribuirle un carácter ceremonial, administrado por mitimaes altiplánicos y con el servicio de la población local. Junto al yacimiento vecino de Pachica contribuyen a una mejor comprensión de la naturaleza de la presencia inca en la sierra de la periferia del Collasuyu.
\end{abstract}

Palabras claves: Andes Centro Sur, valle de Camarones, Inca provincial, arqueología de asentamiento, sitio ceremonial.

We describe an inca site located in the sierra of Camarones basin in northern Chile. We analyze the architectonic features and the cultural remains of the different sectors that compound the site. We argue that the site had a ceremonial function and that it was administered by altiplano mitimaes, with the help of the local population. Saguara and the nearby site of Pachica, provide a better understanding of the nature of the inca presence in the sierra of the Collasuyu periphery.

Key words: South Central Andes, Camarones valley, provincial inca, settlement archaeology, ceremonial site.

La utilización de la investigación arqueológica en conjunto con la documentación etnohistórica, por su mutua realimentación, ha demostrado ser la mejor táctica para comprender el imperio inca en sus múltiples facetas (Murra 1975a; Julien 1982). Sin embargo en regiones como en el norte de Chile, donde dicha documentación es escasa, es necesario apoyarse mayormente en las interpretaciones derivadas de la arqueología.

Un imperio en continua expansión como el inca crea un proceso dinámico que condiciona un cambio permanente en las relaciones núcleo-periferia $\mathrm{y}$ en los mecanismos de control directo o indirecto del estado sobre las etnias subyugadas (Stanish 1997). Se explica entonces la imposibilidad de generalizar sobre la naturaleza y características de los mecanismos de control empleados por la administración inca en las diferentes provincias del imperio, y se deduce la importancia que los estudios específicos de determinados yacimientos o vestigios incas ofrecen para lograr una mejor visión de la variabilidad del control inca sobre sus territorios periféricos.

En este trabajo damos a conocer el yacimiento inca de Saguara que complementa la información proporcionada en una publicación anterior sobre el yacimiento vecino de Pachica (Schiappacasse y Niemeyer 1998); y permite una mejor comprensión de la influencia ejercida por el inca en el sector serrano de la quebrada de Camarones, en el Collasuyu, actual I Región del territorio chileno.

\section{Descripción del Asentamiento}

El yacimiento inca de Saguara (Niemeyer et al. 1971) se localiza en la quebrada homónima, tributaria del río Camarones, a una cota de 3.050 msnm, en el lugar del pueblo actual de Saguara (Figura 1). Se accede a éste, sea desde el poblado de Pachica, remontando a pie el curso de la quebrada en aproximadamente media jornada de camino, o desde el poblado de Esquiña o Isquiña, con animales de silla por una huella tropera que se inicia con una violenta subida. Toma alrededor de una hora en alcanzar la cumbre; en ella hay un pequeño calvario, a lo que sigue un breve descenso para cruzar la quebradilla de las Vizcachas y posteriormente a través de un suave plano inclinado por el flanco sur de la quebrada de Saguara se alcanza el poblado en aproximadamente dos horas y

$\dagger \quad$ Este manuscrito fue recibido, en su versión corregida, pocos días antes de la partida de Virgilio. El texto se ha mantenido sin modificaciones, salvo correcciones para el formato editorial de Chungara.

* Sociedad Chilena de Arqueología. Ahumada 312, Oficina 218, Santiago Centro.

Recibido: septiembre 2001. Aceptado: marzo 2002. 


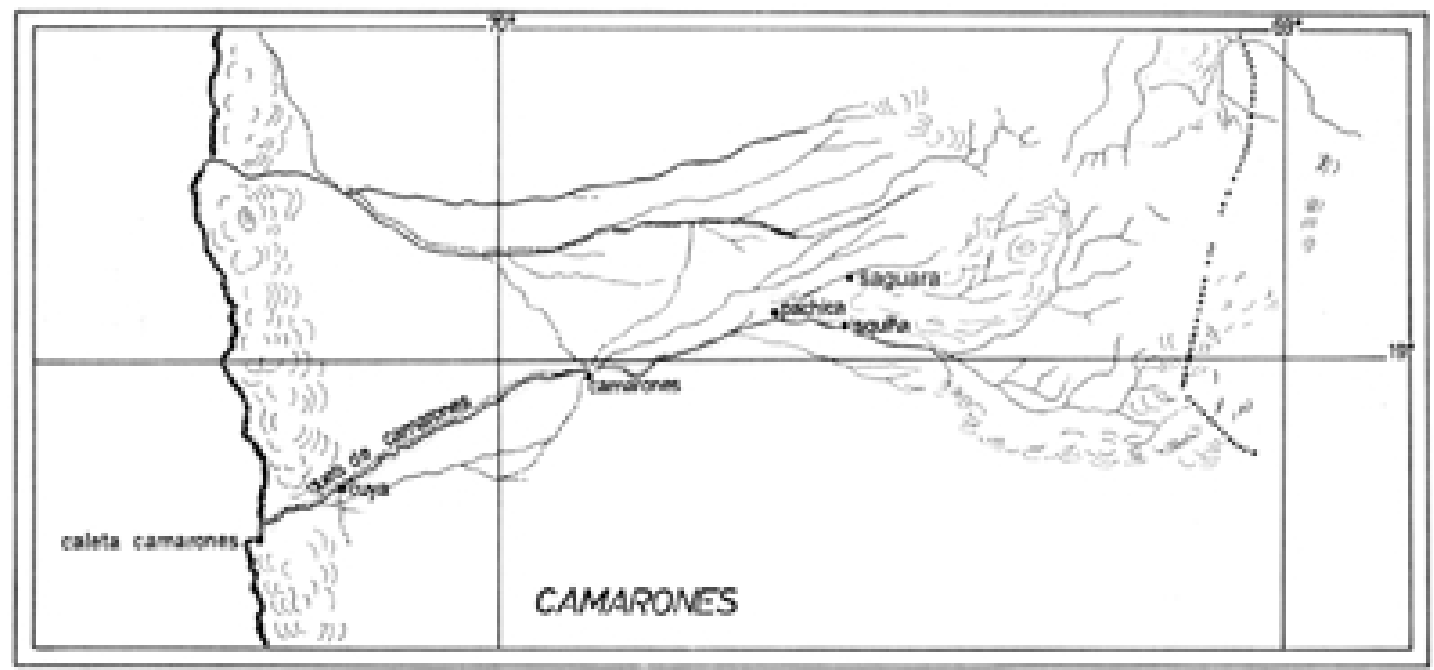

Figura 1. Mapa del valle de Camarones.

Map of the Camarones valley.

media. Años después de nuestra primera visita al lugar en 1970, se trazó un camino vehicular que permanece intransitable gran parte del año por las lluvias de verano. El poblado actual se compone de ocho viviendas, pero sólo dos de ellas estaban ocupadas permanentemente con un total de tres pobladores durante las dos décadas que, de manera esporádica, concurrimos al lugar. El entorno del poblado constituye un microclima con abundante irradiación solar y un clima cálido en el día y templado por la noche. El agua es de vertiente y de excelente calidad, aunque escasa en la actualidad. Se acumula durante la noche en un estanque o "cocha" para ser distribuida por turnos en el día, mediante un sistema de canales, en el riego de unas pocas eras de cultivo escalonadas y situadas en los flancos de la quebrada; abarcan una extensión no mayor de 1,5 há. A juzgar por la evidencia de eras de cultivo no utilizadas en la actualidad, en una superficie de aproximadamente 8 há, los recursos hidrológicos debieron ser más abundantes en el pasado. Se cultiva alfalfa, maíz, orégano y algunos frutales, en especial tunas y tumbos.

El yacimiento arqueológico se distribuye hacia ambos lados de la quebrada pudiéndose reconocer seis sectores (Figura 2). Simultáneamente a la individualización de las estructuras arquitectónicas prehispánicas de cada sector y su levantamiento topográfico, se realizó la colecta superficial, no selectiva, de material cultural. Con posterioridad se excavaron algunos recintos du- rante dos temporadas de campo en los años 1971 y 1979.

El sector denominado Saguara 1 se localiza en el flanco sur y por sus características lo dividimos en tres áreas (Figura 3). Hay un área residencial prehispánica adosada a la quebrada que está obliterada parcialmente por el poblado actual conformado por ocho viviendas de estilo arquitectónico aymara, con techumbre de paja de dos aguas y cimientos rectangulares de piedras reutilizadas de las antiguas estructuras. Solamente permanecen a la vista los restos de 12 recintos prehispánicos de planta rectangular o subrectangular, exceptuando dos de planta circular a elíptica. La superficie de este poblado antiguo alcanza aproximadamente a $6.500 \mathrm{~m}^{2}$ y la sumatoria de los recintos a $370 \mathrm{~m}^{2}$.

La segunda área se localiza en el piedemonte a espaldas del poblado, detrás de tres viviendas agrupadas en su extremo más oriental; corresponde a un conjunto de 20 estructuras compatibles con depósitos o silos cilíndricos aéreos aislados, tipo qollcas exceptuando dos parejas de silos pareados. Poseen paredes de pircas de doble hilera de piedras unidas con argamasa, con $0,60 \mathrm{~m}$ de espesor. El diámetro interior va de 0,80 a $1,40 \mathrm{~m}$; los mejores conservados ofrecen varias hiladas de piedra con alturas que llegan hasta $1,20 \mathrm{~m}$.

Siempre en el piedemonte, pero hacia el poniente y a espaldas del núcleo del poblado, se distingue la tercera área que concentra un conjunto de 83 estructuras, algunas claramente diferencia- 


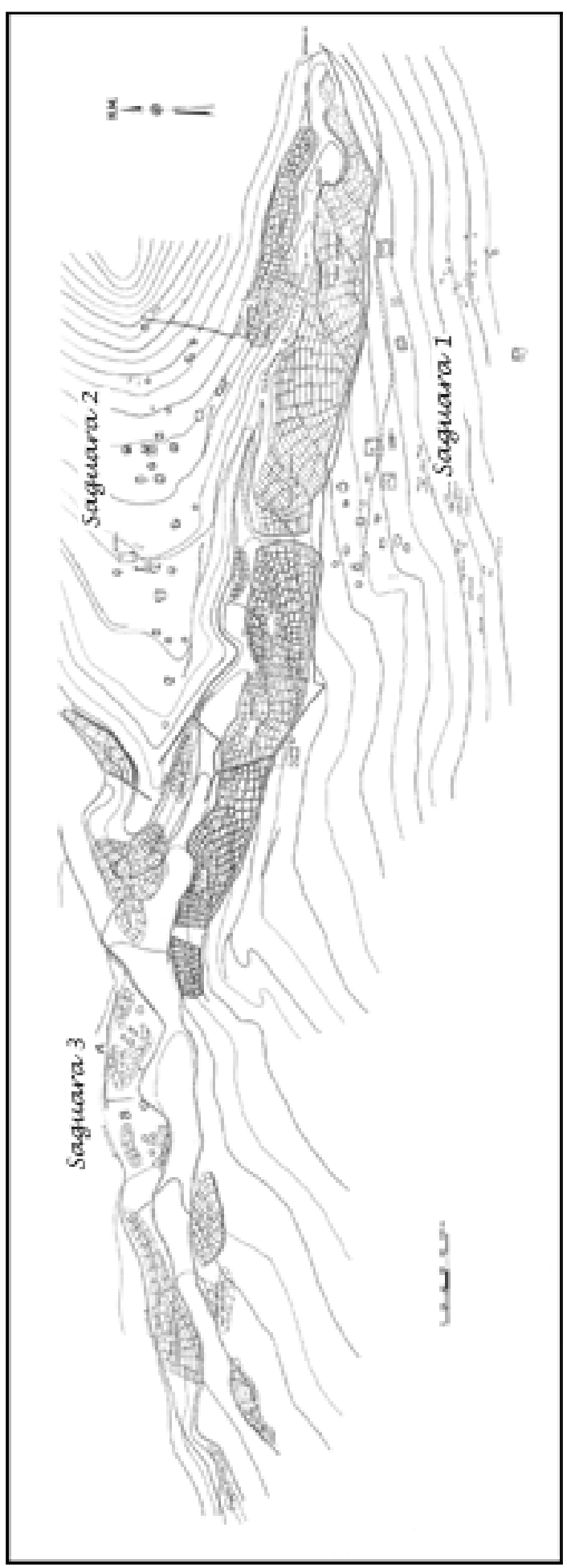

Figura 2. Plano general del asentamiento inca de Saguara. Map of Saguara inca settlement. das como sepulturas y otras como depósitos o silos, mientras que las restantes no pudieron ser diferenciadas por poseer algunos rasgos en común. Es posible que algunas sepulturas hayan sido reutilizadas con posterioridad como depósitos, a semejanza con el yacimiento vecino de Pachica (Schiappacasse y Niemeyer 1998). En un gran rodado de bloques rocosos se adosan alrededor de 20 sepulturas de cistas aéreas aglutinadas tipo nicho, la mayoría destruidas con restos óseos muy deteriorados y fragmentados, aunque algunas pudieran estar intactas. Hay otro conjunto de cistas subterráneas de planta circular o poligonal, con revestimiento de piedras lajas y techadas con falsa bóveda con diámetros interiores de 0,50 a $1 \mathrm{~m}$. El resto corresponde a cistas aéreas de techo abovedado con técnica de falsa bóveda, de planta circular o poligonal. De la limpieza realizada de algunas de estas estructuras abiertas, merece mencionarse el hallazgo en un silo cilíndrico de un hacha de cobre o bronce y de una cuenta de malaquita.

El sector del yacimiento denominado Saguara 2 se sitúa en el lado opuesto de la quebrada, sobre una explanada de forma triangular delimitada por dos quebradas, la principal o de Saguara, y otra secundaria afluente de ella (Figura 4). Actualmente existe una pequeña iglesia levantada hacia el extremo del vértice de este triángulo que conforma la explanada. Ella está circundada por un muro perimetral de planta rectangular que abarca una superficie de $7 \mathrm{~m}$ por $16,5 \mathrm{~m}$.

Sin duda la construcción prehispánica de mayor significación de este sector está constituida por una estructura aérea, elevada $2 \mathrm{~m}$ por sobre el nivel del suelo situada en el centro de la explanada, enfrentando a la iglesia. Está formada por la acumulación de piedras y tierra constituyendo una pirámide truncada de base rectangular, mide 23,50 $\mathrm{m}$ de longitud por 11,20 $\mathrm{m}$ de ancho. Los taludes están mal conservados debido a la extracción de los bloques canteados que conformaban los escalones y que se utilizaron en los cimientos de la iglesia. Sin embargo, en el costado oriente se conserva una gradería de cinco peldaños de $0,35 \mathrm{~m}$ de ancho cada uno (Figura 5).

Esta construcción posee todos los elementos arquitectónicos y las dimensiones que caracterizan las plataformas ceremoniales o ushnu de los asentamientos incas meridionales y que serán analizados en la discusión. En tiempos recientes, se ha levantado sobre el extremo norte de la platafor- 


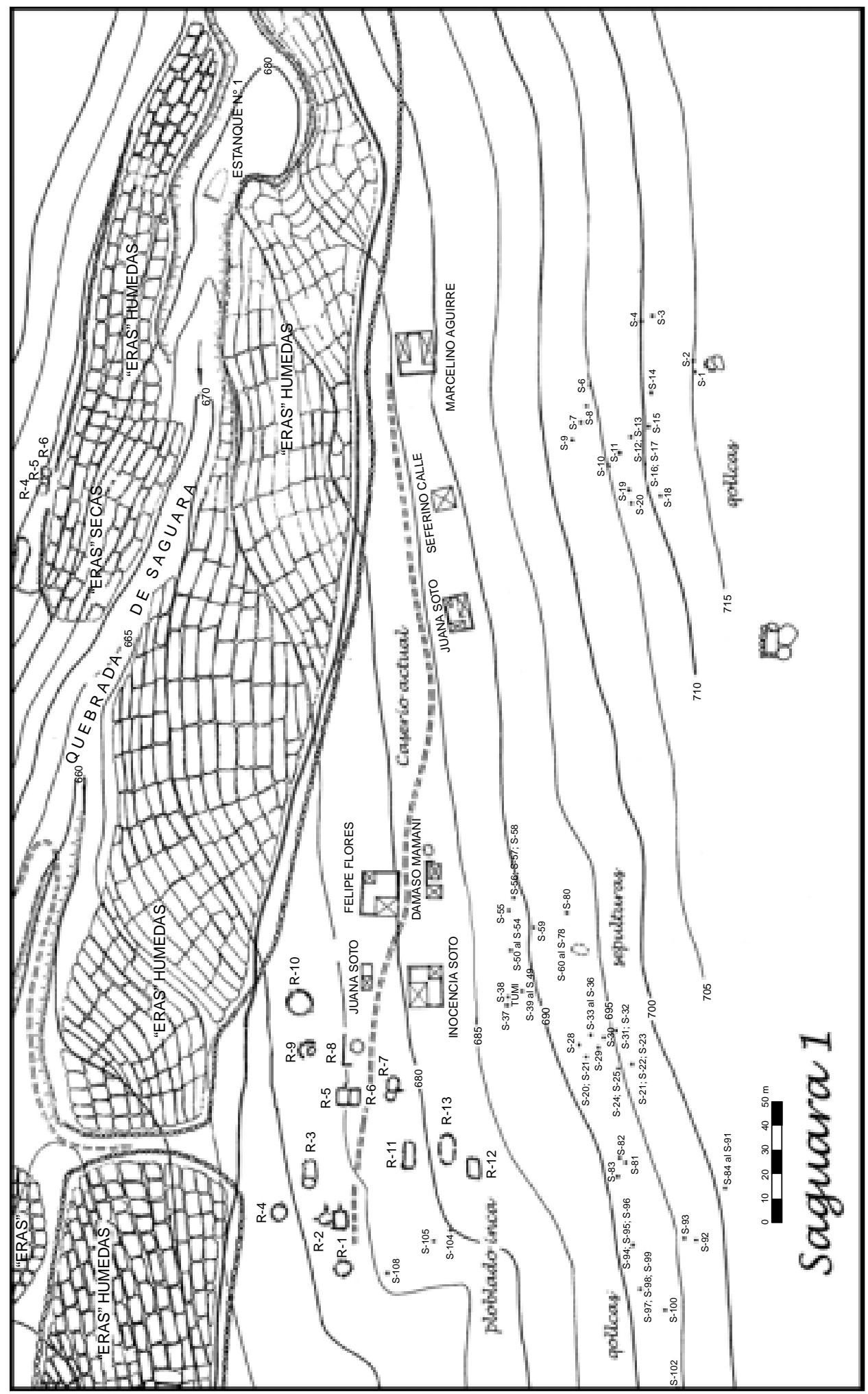

Figura 3. Plano del sector Saguara 1.

Map of Saguara 1 sector. 


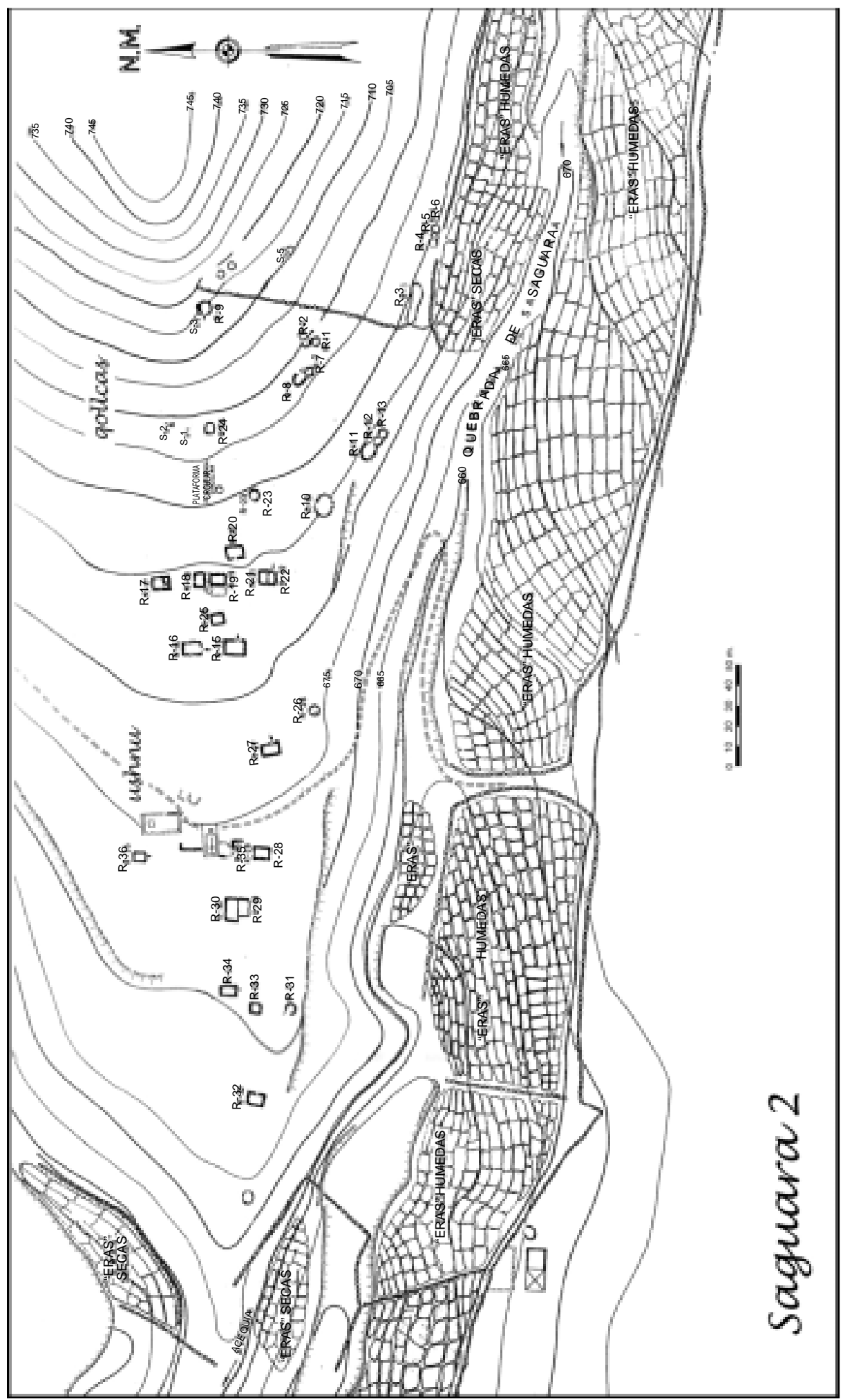

Figura 4. Plano del sector Saguara 2.

Map of Saguara 2 sector. 


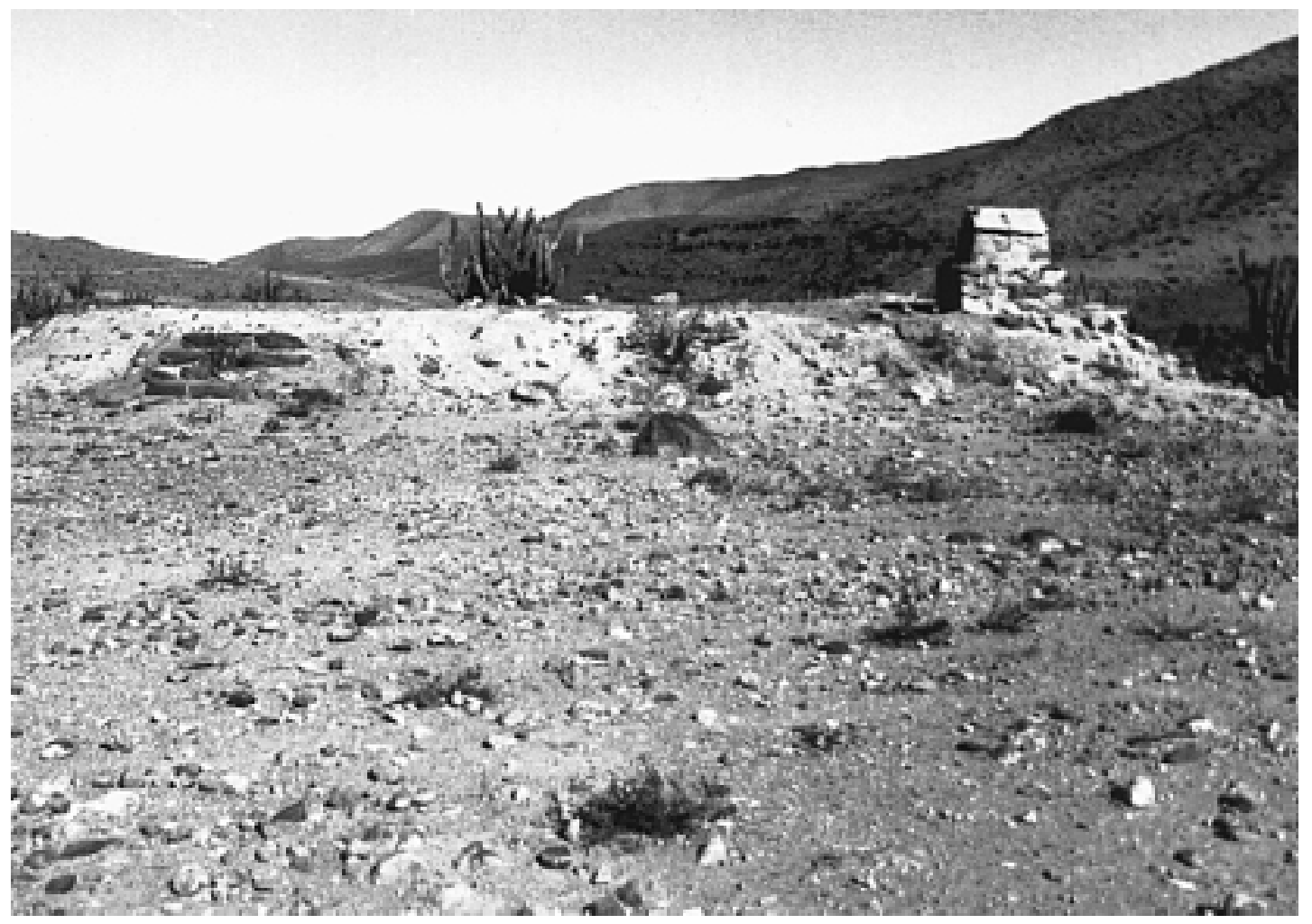

Figura 5. Vista desde el oriente de la plataforma o ushnu de Saguara 2 con restos visibles de la escalinata en el extremo izquierdo y el calvario intrusivo en el extremo opuesto.

View from the east side of the platform or ushnu at Saguara 2, with remains of a stair over the left side, and the intrusive calvary over the opposite side.

ma un calvario de $1,80 \mathrm{~m}$ de altura; frente a éste había una excavación que resultó corresponder a una tumba saqueada. Nuestro guía ya nos había adelantado que allí estaba enterrado un "rey". Su limpieza mostró en planta el aspecto de un brocal formado por piedras más o menos paralelepipédicas de 30 a $40 \mathrm{~cm}$ de largo, seguida de una excavación cilíndrica con revestimiento de piedras regularmente dispuestas. En su fondo se abría hacia el norte una cavidad ampollar. El cilindro principal estaba ocupado por el esqueleto incompleto, en mal estado de conservación, sin el cráneo, de un individuo adulto en posición sedente con piernas flexionadas, apoyando su espalda hacia el costado sur y enfrentando la cavidad ampollar. Ésta albergaba el esqueleto de un infante también flexionado en decúbito lateral derecho, junto al tronco dispuesto verticalmente de un cardón seco. El hallazgo en la vecindad de una clavícula y de algunas epífisis de huesos largos pertenecientes a un individuo inmaduro, señala la presencia original de una tercera inhumación en una tumba colectiva. No se encontró ofrenda alguna. Parece evidente que este enterratorio indígena es de carácter intrusivo y de data postincaica, cuando la plataforma ya había perdido el significado y función para la que había sido erigida en el asentamiento.

El resto del sector Saguara 2 está constituido por tres conjuntos de estructuras; el primer conjunto comprende 31 recintos aislados que cubren la mayor parte de la explanada. Son de planta predominantemente rectangular, dos de ellos circulares; solamente dos están contiguos. Las dimensiones de los recintos rectangulares son bastante similares entre sí, de 8 por $5 \mathrm{~m}$ aproximadamente y superficie interior de $45 \mathrm{~m}^{2}$ de promedio. La construcción del muro perimetral de la capilla alteró los recintos 26 y 35 y probablemente de otros, a juzgar por restos de cimientos. Los muros de los recintos están bien constituidos, de doble hilera y varias hiladas que pueden llegar hasta siete, con alturas de hasta 1,20 m, si bien en algunos hay 
además derrumbes hacia el exterior. El recinto 15 está en mejor estado de conservación por ser ocupado en ciertas festividades que se realizan en el pueblo.

Los muros de 0,50 a $0,80 \mathrm{~m}$ de espesor y relleno de ripio fino y tierra o de argamasa, poseen la hilada de cimiento conformada por piedras más grandes, bien plantadas y los paramentos interiores verticales. Los accesos están bien configurados, orientados generalmente hacia el este o el sur, con dinteles con jambas de remate de muros y umbral de 0,20 m de altura. El aparejo de estos recintos (Figura 6) debe asimilarse al tipo rústico con jambas desbastadas descrito por Agurto (1987).

Los recintos 16 y 34 poseen el vano protegido por un murete curvo de doble hilera. Creemos que esta protección de la entrada sería un rasgo propiamente inca porque además se manifiesta en un asentamiento inca del litoral, en la desembocadura de la quebrada de Camarones (Schiappacasse y Niemeyer 1989). Solamente el recinto 17 presenta una hornacina de 25 por $30 \mathrm{~cm}$ y $40 \mathrm{~cm}$ de profundidad, de dos diseños: uno superior trapezoidal y otro inferior rectangular. De estos recintos con cimientos de muro doble, seis se excavaron en forma completa y los restantes, exceptuando cuatro, se exploraron mediante cuadrículas o pozos de sondeo. En ningún recinto se observaron poyos, hoyos para postes o fogones bien conformados en el interior y exterior. Sólo en el rincón sureste del recinto 34 adosado al muro hay un fogón estructurado enmarcado por piedras y asociado a varios

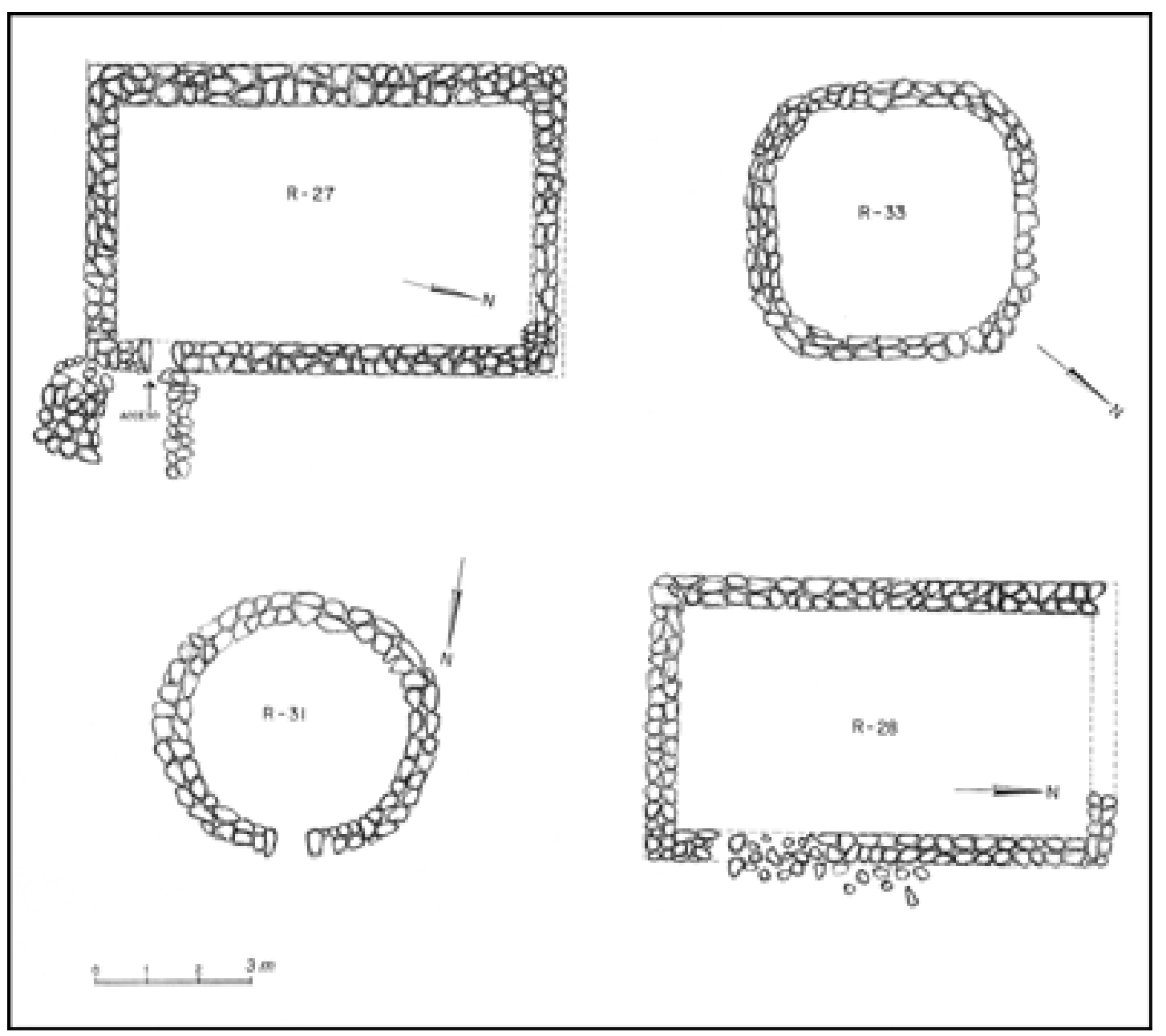

Figura 6. Planta de recintos de muro doble de Saguara 2.

Plan view of double wall structures at Saguara 2. 
implementos de molienda, pero perteneciente a una reocupación posterior, en tiempos coloniales, por su asociación a herraduras, hojas corridas de cuchillos, cuenta veneciana, fragmentos de tinajas y de fuentes coloniales, semejantes a las descritas en el sitio vecino de Pachica (Schiappacasse y Niemeyer 1998). La excavación del resto del recinto arrojó sin embargo una cantidad significativa de artefactos culturales prehispánicos. En situación periférica, marginal, y hacia el extremo oriental del sector de Saguara 2, hay otro conjunto de 14 recintos de muros bajos de planta subcircular alargada o arriñonada, de cimientos simples, mal conservados, de una hilera y de una hilada de bolones que a veces se complementan con bloques naturales de diferente tamaño. Las dimensiones de estas construcciones son variables entre 4 a $10 \mathrm{~m}$.

Los recintos 3, 4, 5 y 6 están contiguos y forman parte del conjunto mayor. El recinto 3 es el más amplio, de forma arriñonada de $18 \mathrm{~m}$ de longitud y ancho promedio de $4 \mathrm{~m}$. Más que un recinto podría considerarse como una plataforma adaptada a la ladera. Está limitada al poniente por una pirca que baja del cerro siguiendo una línea de máxima pendiente. Ésta intercepta otra pirca que corre según una curva de nivel que sirve de defensa a los cultivos por el lado norte. La pirca que baja del cerro probablemente haya tenido un rol defensivo contra los efectos de las copiosas lluvias de verano. Los recintos 4, 5 y 6 son circulares, de diámetro interior de 2,40 a 3,30 m. El recinto 3 se excavó en su totalidad mediante cuadrículas. La excavación de los recintos 4, 5 y 6 arrojó escaso material cultural, entre el cual es importante señalar la presencia de un pendiente metálico o lauraque en el recinto 4. Por último, el tercer conjunto del sector de Saguara 2 se sitúa más al oriente, alejado de los anteriores, en la ladera que enmarca la base de la explanada triangular; está conformado por siete silos aéreos cilíndricos o qollcas de 1,20 m de diámetro interior; semejantes a los descritos en Saguara 1. En cuatro de ellos se colectó material cultural en la limpieza de su interior.

El sector individualizado como Saguara 3 está algo distante de los anteriores, aguas abajo, en la confluencia de las dos quebradas que limitan la gran explanada. Está compuesto por dos grupos de recintos separados por una distancia de aproximadamente $130 \mathrm{~m}$, rodeados por eras secas de cultivo.
Ocupan entre ambos una superficie de $1.300 \mathrm{~m}^{2}$ (Figura 7). El primer grupo de recintos o Saguara $3 \mathrm{~A}$ consta de cinco recintos, de los cuales cuatro son circulares semisubterráneos y se presentan como depresiones delimitadas por muros de dos a tres hiladas y doble hilera de piedras calzadas. El quinto recinto difiere del patrón anterior por su planta subrectangular con muros de cuatro hiladas de una hilera y no parece ser contemporáneo con ellos. Se eligió para su excavación el recinto individualizado con el número 3 , de planta circular de 5,80 m de diámetro interior y perímetro delimitado por muros de piedra dispuestos en dos hileras; en el sector mejor conservado presenta hasta seis hiladas. La hilada inferior, que hace de cimiento, está constituida por grandes bloques parados de 40 a $60 \mathrm{~cm}$ por lado y planos al interior; por la presión del terreno se advierten un poco inclinados hacia el interior. Su excavación demostró un abundante relleno de arena y un piso bien definido a $1,20 \mathrm{~m}$ del nivel del suelo. Entre las piedras que se extrajeron de su interior por el derrumbe de los muros, se reconoció un mortero pequeño poco profundo de planta subrectangular de $20 \times 19 \times 9 \mathrm{~cm}$ y con una depresión de $2 \mathrm{~cm}$ de profundidad. El depósito arqueológico, que fue más bien exiguo, se caracteriza por la abundancia de hojas líticas de azadón, enteras o fragmentadas, algunas con filos desgastados por el uso y fragmentación cerámica en su mayoría no decorada. Vecino al recinto hay un depósito subterráneo o troje de boca cuadrangular de $0,50 \mathrm{~m}$ por lado, constituida por un brocal de piedras grandes y un cuerpo cilíndrico también de $0,50 \mathrm{~m}$ de profundidad; su limpieza expuso el fondo con su sello natural.

El segundo grupo o Saguara 3B (Figura 7) también está compuesto de cinco recintos, todos circulares, de análogas características constructivas que los del grupo anterior. En el recinto numerado 8 se halló un mortero de piedra fragmentado, además de hojas líticas quebradas. Entre ambos sitios suman un área de $226 \mathrm{~m}^{2}$, con un promedio de 22,5 $\mathrm{m}^{2}$ por recinto.

Hacia la ladera derecha del valle se individualizó otro grupo de cuatro recintos circulares, tres de ellos se denominaron Saguara 3C. Vecinas a este conjunto y al pie de unos farellones de basalto se sitúan cinco trojes o silos subterráneos, tapadas por piedras lajas de andesita. La andesita de estos farellones constituyó la cantera de materia prima 


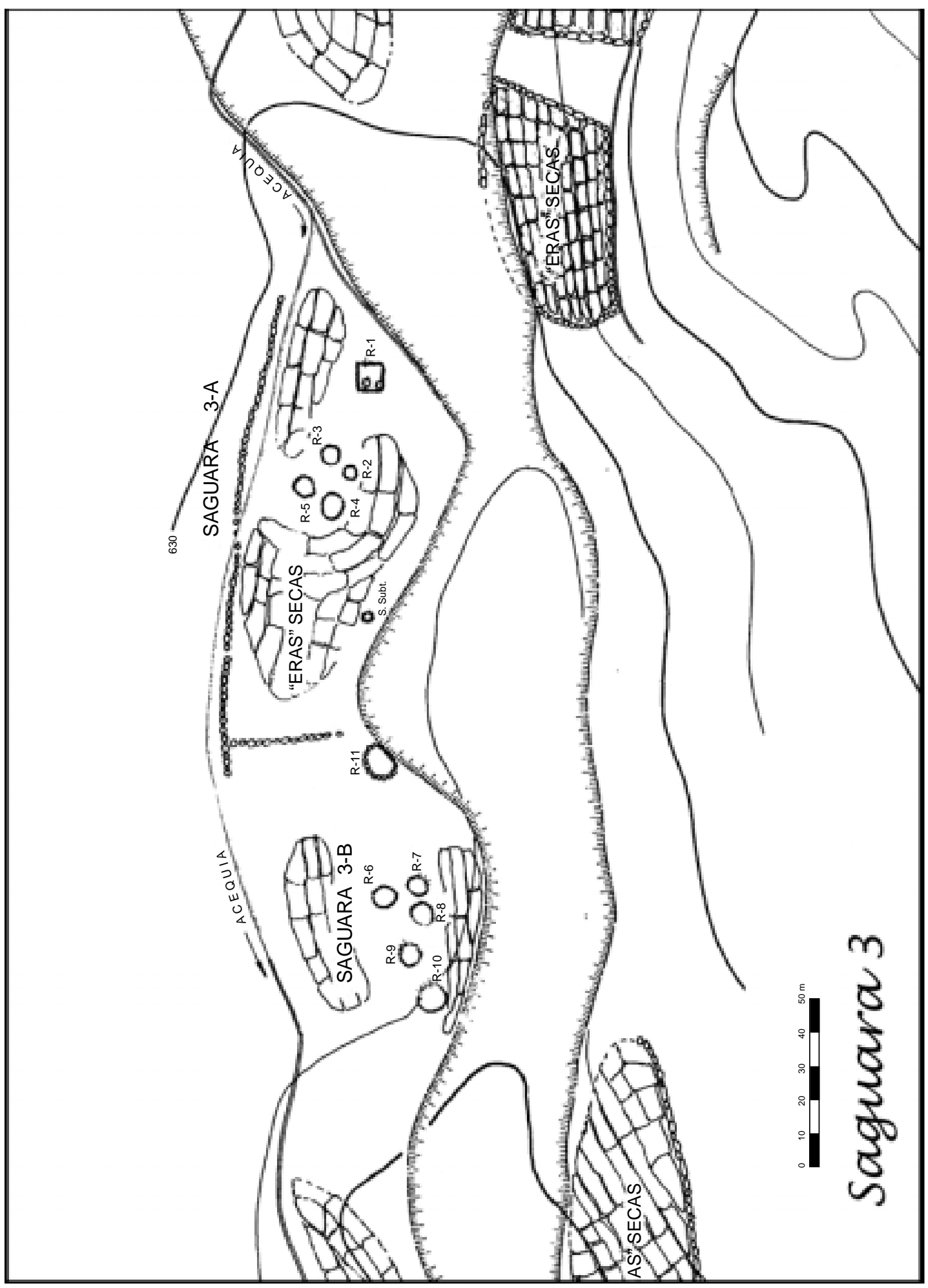

Figura 7. Plano del sector Saguara 3.

Map of Saguara 3 sector. 
en la fabricación de las hojas para implementos agrícolas.

La colecta superficial y las excavaciones realizadas en el sector de Saguara 3 arrojaron un material cultural bastante diferente al de Saguara 1 y 2. Lo más característico es la abundancia de hojas líticas de azadón de andesita completas o fragmentadas y su preforma. De menor frecuencia son desechos de talla de calcedonia y hojas bifaciales fragmentadas. La fragmentación cerámica en su mayor parte corresponde a cántaros no decorados, pero en los especímenes decorados si bien hay algunos fragmentos incaicos y variedades Negro sobre Rojo de cántaros y escudillas, lo más llamativo y de mayor frecuencia es la presencia de cántaros con decoración tipo Charcollo. Son de notar además escasos fragmentos estilo Arica: Pocoma y Gentilar.

En relación con los recintos circulares semisubterráneos que caracterizan Saguara 3, localizamos un par de recintos similares, de $5,5 \mathrm{~m}$ y $4 \mathrm{~m}$ de diámetro respectivamente, en una pequeña explanada producida por el escombro de falda situada a un par de kilómetros de la desembocadura de la quebrada de Saguara en el río Camarones, entre las localidades de Isise e Iquilta; se colectó escasa fragmentación cerámica corriente.

En la base del farellón que delimita por el norte la quebrada de Saguara se localizó una cueva que designamos Saguara 4. Su entrada está cerrada actualmente por una pirca, porque se utiliza como corral. Posee $7 \mathrm{~m}$ de fondo y la entrada mide 4,5 $\mathrm{m}$ de ancho por 2,9 $\mathrm{m}$ de alto. En la pared, a mano izquierda de la entrada, se observan dos grupos de pinturas: la primera en rojo obscuro, permite reconocer dos llamos seminaturalistas, la otra de un rojo anaranjado es poco discernible y al parecer representa motivos de vegetales. Más hacia el fondo de la cueva hay otros dos manchones de pintura roja no descifrables. Se practicó un pozo de sondeo detectándose una capa de guano de 30 $\mathrm{cm}$ de espesor a la cual sigue un delgado estrato de ocupación carbonoso. De este pozo y de la colecta realizada en la escarpa de la cueva se obtuvo un material cultural semejante al de Saguara 3.

Un alero situado a media altura en el mismo farellón, pero aguas más abajo, se denominó Saguara 5. Está constituido por cinco silos o depósitos circulares de forma abovedada y adosados a la pared del alero. Se colectó una hoja de azadón fragmentada y una lasca espesa de liparita astillada en un borde, además de escasa fragmentación cerámica no demostrativa. Por último, como Saguara 6, se identificó otro alero situado aguas más abajo que el anterior pero con un abundante depósito de guano ovino. Sin embargo, no proporcionó material cultural.

Las diferencias arquitectónicas señaladas entre los tres sectores principales que conforman el yacimiento de Saguara se manifiestan también en las características del depósito arqueológico, que se analizarán en detalle en la descripción del material cultural.

\section{Cronología Absoluta}

Del yacimiento de Saguara se dispone de cuatro fechas de TL (Tabla 1), obtenidas de fragmentación cerámica (Schiappacasse y Niemeyer 1988). El rango de dispersión de las fechas es excesivamente amplio. La fecha de la muestra UCTL 120 es difícil de aceptar sobre la base de toda la información disponible con relación al estilo Cuzco. Las otras tres fechas serían más coherentes si se utiliza la variación estadística de 2 DS.

Tabla 1. Dataciones por Termoluminiscencia Thermoluminiscense dating

\begin{tabular}{lllll}
\hline Sitio & N $^{\circ}$ muestra & Datación & Estilo & N $^{\circ}$ recinto \\
\hline Saguara 2 & UCTL 117 & $1350 \pm 80$ d.C. & Saxamar & Recinto 15 \\
Saguara 2 & UCTL 118 & $1520 \pm 28$ d.C. & Inca provincial & Recinto 15 \\
Saguara 2 & UCTL 119 & $1560 \pm 35$ d.C. & Inca Provincial & Recinto 34 \\
Saguara 2 & UCTL 120 & $1230 \pm 50$ d.C. & Inca Cuzco & Recinto 3 \\
\hline
\end{tabular}




\section{Descripción del Material Cultural}

\section{Alfarería}

La fragmentación cerámica proveniente de la colecta de superficie y de las excavaciones realizadas en los diferentes recintos, se clasificó de acuerdo al tratamiento de la superficie en: cerámica no decorada (o corriente), cerámica decorada y cerámica colonial.

\section{Cerámica no decorada}

Está representada casi exclusivamente por Formas Restrictas Independientes Complejas pertenecientes a dos grandes grupos: el más frecuente corresponde a cántaros de tamaño grande a mediano, de cuerpo globular y cuello cilíndrico o tronco cónico, premunidas de asas acintadas situadas en el ecuador del cuerpo en los planos vertical u horizontal. En su mayoría el fondo es plano y angosto de 40 a $80 \mathrm{~mm}$ de diámetro. El diámetro de la boca varía entre 220 y $240 \mathrm{~mm}$ y 7 a $8 \mathrm{~mm}$ de grosor. $\mathrm{La}$ segunda frecuencia está representada por ollas de tamaño mediano a pequeño y cuerpo globular con cuello corto inflexionado convexa; las asas verticales van desde la boca a la base del cuello o se sitúan en el ecuador del cuerpo. La superficie es alisada y aproximadamente el $20 \%$ del total de la fragmentación no decorada presenta manchas de hollín. El diámetro de la boca varía de 120 a 160 $\mathrm{mm}$. Menos frecuentes que los dos grupos anteriores están representados jarros de tamaño mediano, de cuello largo inflexionado y con un asa vertical desde la boca al cuerpo, premunida de un protúbero en su extremo inferior. La Forma Restricta Simple está representada solamente por el espécimen completo de un cuenco pequeño hemisférico de superficie interior alisada y con moldeado digital exterior que presenta manchas de cocción; mide 45 $\mathrm{mm}$ de diámetro en la boca y $25 \mathrm{~mm}$ de alto (Figura 8: 2).

La pasta de la alfarería no decorada es bastante homogénea con inclusiones de arena de distribución uniforme de cuarzo, feldespatos y biotita o mica, cocción en atmósfera oxidante con núcleo gris ocasional.

\section{Cerámica decorada}

Posee Formas Irrestrictas Simples y Restrictas Complejas.

\section{Formas Irrestrictas Simples}

(a) Platos o cuencos poco profundos. Correspondiente a la forma $\mathrm{G}$ de Rowe (1944), de 160 a 220 $\mathrm{mm}$ de diámetro con un asa horizontal o la representación de una cabeza ornito o zoomorfa y dos pequeños apéndices en el polo opuesto, algunos con una ligera depresión central. La decoración varía con ejemplares de superficie bruñida y motivos en color negro de hileras de llamos muy estilizados, algunos semejan a la letra $\mathrm{H}$ o a "comas", característicos del tipo Saxamar (Figura 9: 3). Otros platos muestran decoración geométrica conformada por una banda de disposición diametral de líneas paralelas que enmarcan hileras de puntos, de triángulos o de rombos de color negro sobre la superficie engobada de color rojo. Además del estilo Saxamar, la forma y decoración de estos platos es de influencia inca cuzqueña.

(b) Escudillas. Pueden distinguirse dos grupos: poco profundas con diámetro de la base mayor de la mitad de la amplitud de la boca, y escudillas más excavadas. El primer grupo es de fondo plano y borde directo ligeramente incurvado con labio redondeado o plano, con 100 a $180 \mathrm{~mm}$ de diámetro en la boca y 6 a $10 \mathrm{~mm}$ en la base. Están recubiertas por un engobe de color rojo con superficie interior bruñida y exterior alisada. La decoración se distribuye en una banda ancha horizontal dispuesta bajo el labio de la superficie interna, de fondo blanco y con motivos de color negro o negro y rojo predominantemente geométricos, que pueden ir asociados a líneas horizontales paralelas, líneas quebradas, hileras de rombos, de triángulos o de círculos con uno o varios puntos centrales (Figura 10: 2-7). Los motivos figurativos fito o zoomorfos son menos frecuentes y representan cabezas de aves o de peces con manchas en el cuerpo (Figura 9: 1,2,4). Hay también algunos fragmentos de escudillas de este tipo con el estilo Saxamar. El segundo grupo de escudillas más profundas posee paredes incurvadas o rectas de labio redondeado y fondo plano o convexo. La decoración, que también compromete la cara interna, es de color negro con motivos geométricos sobre el fondo natural con varias tonalidades de color rojo débil o café rojizo (2.5YR 5/4-8), semejante al de la pasta o bien sobre una superficie con engobe rojo escarlata 10R 4-5/4-6. En un grupo la decoración se distribuye de manera horizontal bajo el borde y los motivos son de lí- 

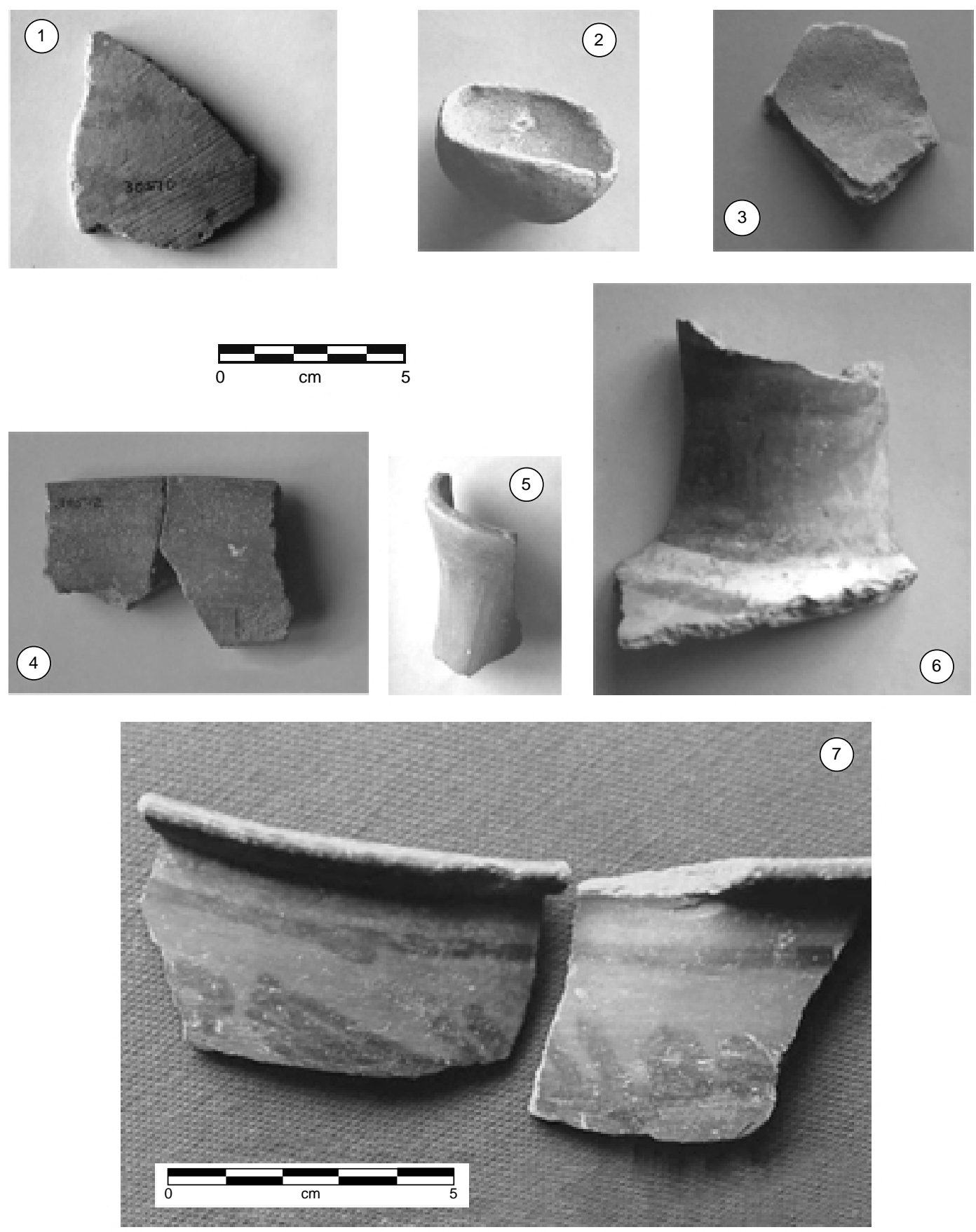

(6)

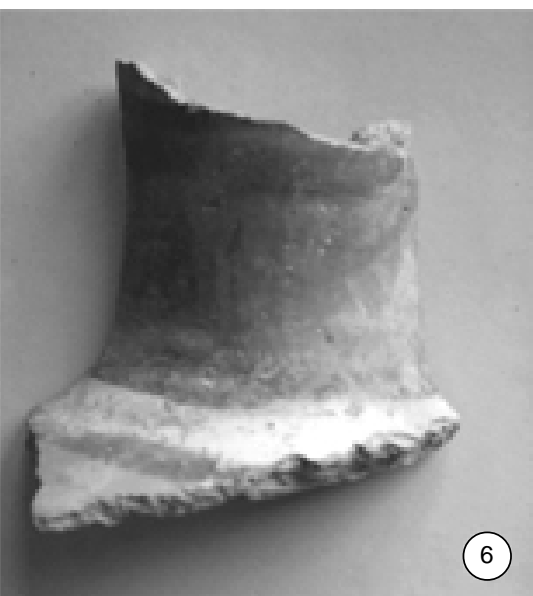

Figura 8. Ceramios Restrictos Simples y Complejos. (a) cuenco con decoración de color rojo sobre superficie natural tipo Charcollo: 1, 3, 4; (b) cuenco pequeño, no decorado: 2; (c) cuello cilíndrico de botella, superficie bruñida color rojo (5R 4/6) y línea negra en el labio: 5; (d) cuello de aríbalo con bandas horizontales negro y rojo sobre blanco: 6; (e) cuenco de estilo intrusivo de superficie bruñida con decoración figurativa de color negro sobre engobe rojo (10R 5/6): 7. Procedencia: Saguara 1: 7; Saguara 2: 2, 5, 6 y Saguara 3: 1, 3, 4 .

Complex and Simple Restricted Pottery Types. (a) bowl with red decoration over plain surface Charcollo type: 1, 2, 3; (b) small bowl with plain surface: 2; (c) cylindrical neck of a bottle, with red polished surface (5R 4/6) and a black line painted on the lip: 5; (d) neck of an Inca jar "aryballus" with black and red horizontal strips on white slip: 6; (e) bowl of intrusive style with polished surface and black figurative decoration on red slip (10R 5/6): 7. Provenience: Saguara 1: 7; Saguara 2: 2, 5, 6, and Saguara 3: 1, 3, 4 . 

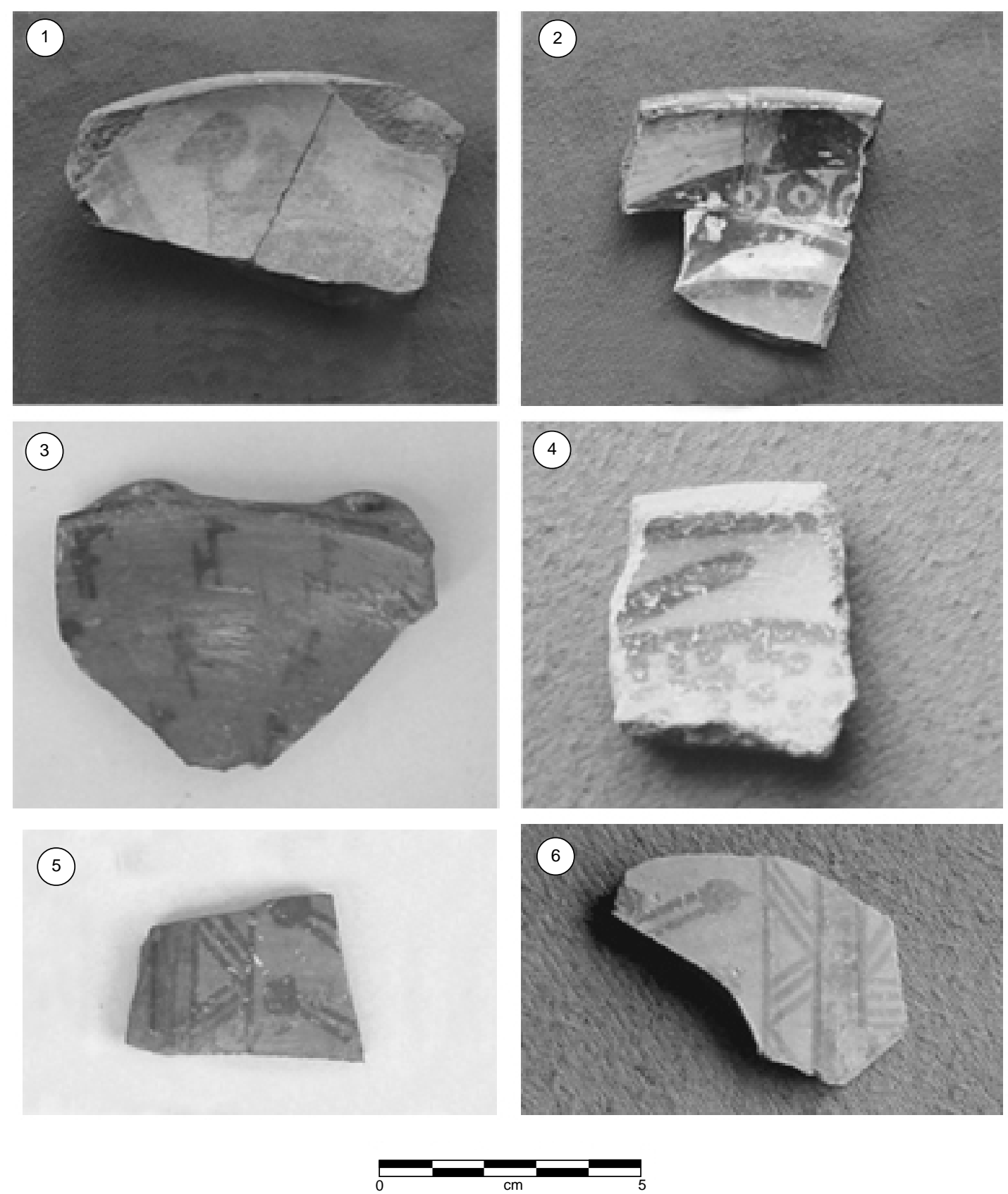

Figura 9. Ceramios no Restrictos y Restrictos Complejos. (a) plato tipo Saxamar: 3; (b) escudillas decoradas con motivos figurativos de aves y peces, color negro y blanco: 1; (c) negro y anaranjado (5YR 6/6: 4): 2 y 4; (d) aríbalo con decoración polícroma imitación Cuzco de colores negro, rojo (7.5R 5/6) y anaranjado (5YR 5/4) sobre fondo rojo (10R 5/8): 5 y 6. Procedencia: Saguara 2, excepto 2 de Saguara 1.

Complex Restricted and Unrestricted Pottery Types. (a) Saxamar type plate: 3; (b) flat bowls with figurative black and white birds and fishes: 1; (c) on black and orange (5YR 6/6:4): 2 y 4; (d) aryballus with polychrome decoration, imitating Cuzco style of black and red colors (7.5R 5/6), and orange (5YR 5/4) on red (10R 5/8): 5 y 6. Provenience: Saguara 2 with the exception of number 2 from Saguara 1. 
neas onduladas o paralelas, hileras de volutas de "S" y de triángulos (Figura 11: 1, 7-9). En otro grupo la decoración es de orientación predominantemente vertical, dispuesta desde el borde hacia el centro del ceramio, con líneas rectas paralelas o convergentes asociadas a líneas onduladas horizontales o a hileras de triángulos de cuerpo lleno o enrejado. Otro motivo lo conforman líneas o bandas entrecruzadas (Figura 11: 2, 3, 4 y 6). Una escudilla completa con decoración vertical muestra restos de un enlucido blanco, fugitivo (Figura 10: 1).

En los platos y escudillas planas la pasta es compacta, dura y de timbre metálico al golpearla. Las inclusiones son de arena fina. La cocción puede ser en atmósfera oxidante de un color rojizo pálido (5YR 6/6) o de color gris homogéneo por cocción en atmósfera reductora a altas temperaturas, seguida por un breve período de oxidación que produce una capa superficial de color claro; este procedimiento parece ser característico de la cerámica inca y ha sido descrito en varios valles del norte y sur peruano (Hayashida 1999). Las características de la pasta como así el grado de cocción en atmósfera oxidante del segundo grupo de escudillas son más variables; también las inclusiones son de arena pero con menor selección del tamaño y de la cantidad.

Las escudillas del primer grupo poseen las características decorativas que hemos atribuido a un estilo inca provincial de origen altiplánico (Schiappacasse y Niemeyer 1988). Por el contrario, la decoración de los cuencos más profundos corresponde a estilos locales de amplia distribución en la región meridional de la cuenca del Titicaca, en territorios de pacajes y carangas (Portugal 1989; Albarracín 1996; Pärssinen y Siiriainen 1999).

\section{Formas Restrictas}

\section{(a) Restrictas Simples}

Solamente están representadas por dos fragmentos atípicos de cuencos; el primero corresponde al fragmento de un ceramio restricto simple de boca ancha de $140 \mathrm{~mm}$ de diámetro con una inflexión angular del borde y labio redondeado (Figura 8: 7). La superficie exterior bruñida lleva la decoración de una hilera horizontal de aves de color negro enmarcada por dos líneas paralelas sobre el fondo engobado rojo (10R 5/6); la pasta es com- pacta de cocción en atmósfera oxidante homogénea; semeja el fragmento 192-001-8 ilustrado por Stanish et al. (1997: 97). El otro fragmento, no ilustrado, pertenece a un ceramio restricto simple de borde directo y labio redondeado de superficie exterior pulida, engobada de color rojo y decorada bajo el borde con una hilera de triángulos invertidos de color negro.

\section{(b) Restrictas Complejas}

(b.1) Cántaros botelliformes o aríbalos. Con la forma A de Rowe (1944), pero de base tronco cónica, no reconociéndose bases cónicas. Poseen mamelones bajo el labio, algunos perforados y, en el cuerpo, protúberos que representan cabezas de llamo o de felino con los ojos demarcados por finas incisiones y algunos con orejas modeladas (Figura 12: 4, 6). Son de tamaño variable con diámetros de la boca entre 100 a $280 \mathrm{~mm}$. La decoración está distribuida preferentemente en el cuello con bandas horizontales de colores alternados sin o con hileras de rombos de color negro agregadas sobre un fondo blanco. El resto del ceramio solamente posee un engobe rojo. El color rojo varía de 10R 4/ $8,7.55 / 6$ y 5 YR $4 / 2$. Cuando el blanco es empleado como motivo se aplica diluido, transparentándose el color de fondo (Figura 12: 1, 2). La decoración en el cuerpo es menos frecuente y se dispone en una banda ancha horizontal o vertical con motivo ajedrezado de colores alternados negro y rojo, o negro y blanco, o hileras de rombos enmarcados por líneas verticales y horizontales (Figura 12: 3, $5,7,8)$. Hay algunos fragmentos de aríbalos más pequeños y de menor espesor y pasta de cocción compacta con superficie bruñida y decoración dispuesta en bandas verticales con hileras del motivo de helecho "fern pattern" o "neck lace" (Rowe 1944; Rydén 1947), enmarcado por líneas verticales y horizontales. Se emplean los colores negro y rojo (7.5R 5/6) sobre un fondo amarillo rojizo (5 YR 6/6) o negro, rojo (5 R 4/3) y anaranjado (5YR $5 / 4$ ) sobre el engobe rojo (10 R 5/8) de base (Figura 9: 5 y 6).

(b.2) Cántaros. Con decoración monocroma de tamaño relativamente grande y cuello inflexionado con superficie pulida y engobada de tonalidades variables de color rojo (10R 5/6 a 7.5R 4/4); la decoración es geométrica de líneas color negro verticales y diagonales entrecruzadas (Figura 13: 3). 

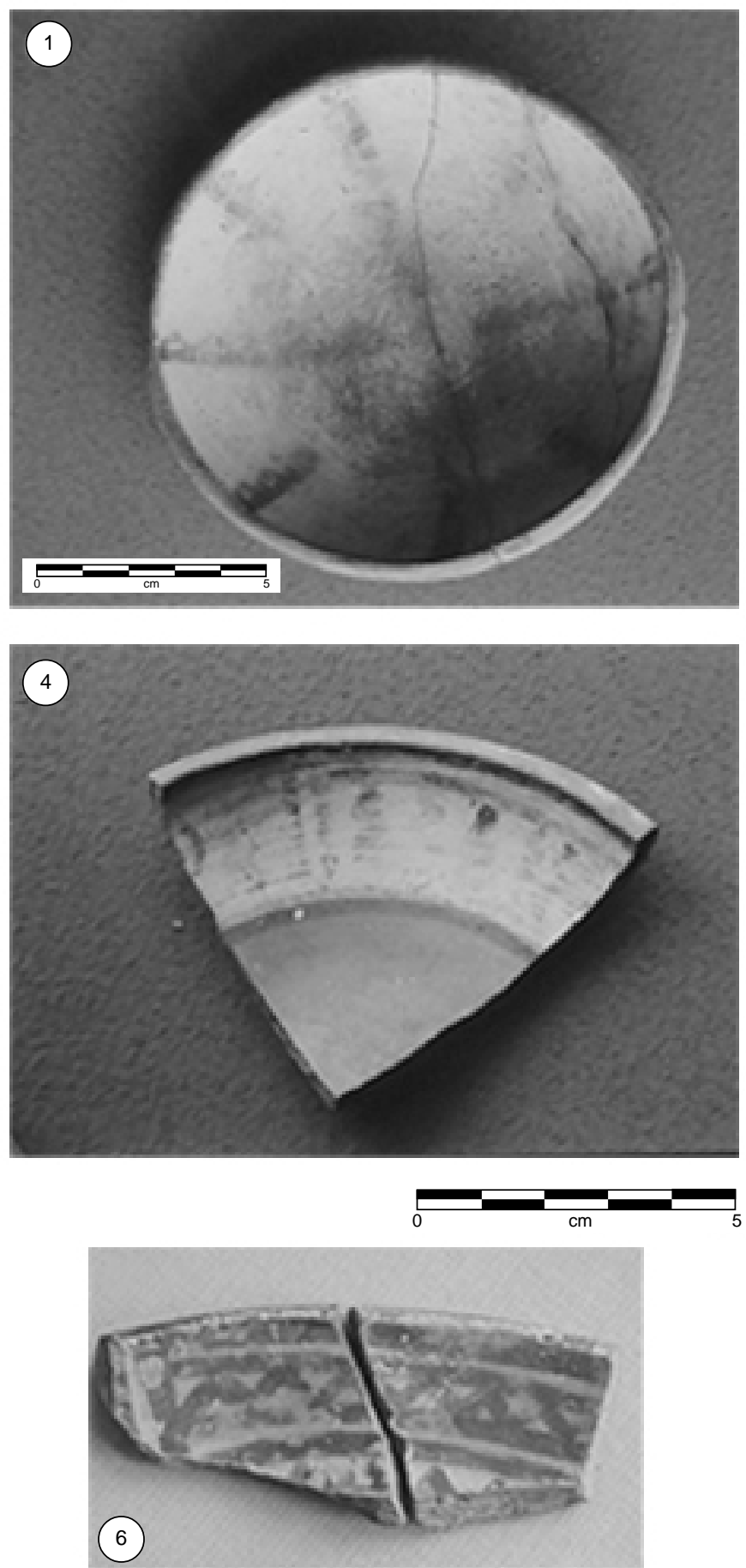
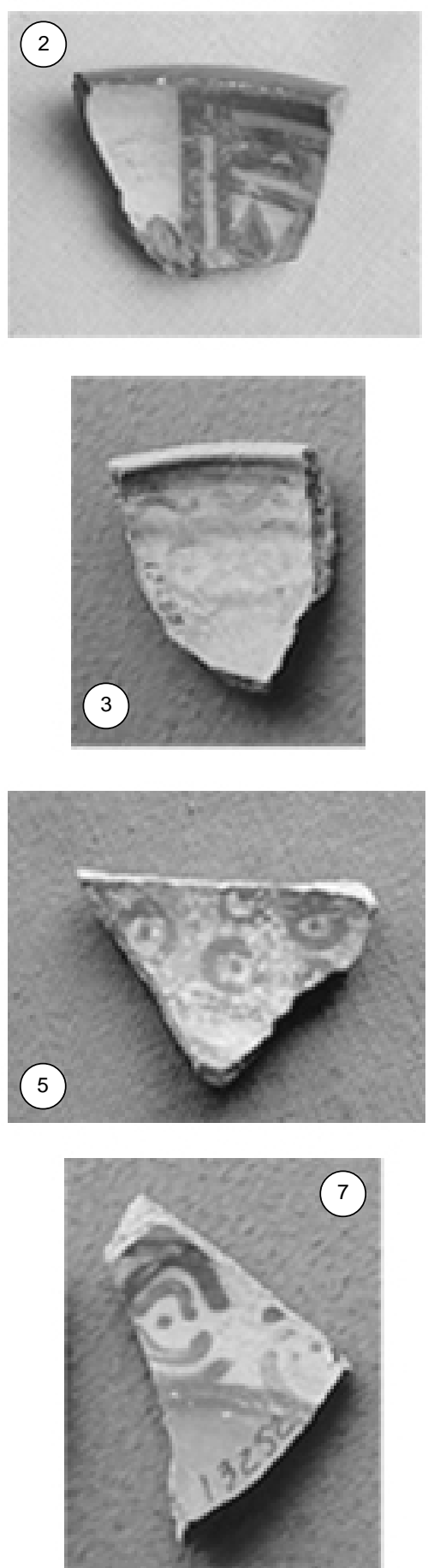

Figura 10. Ceramios no Restrictos: escudillas con decoración geométrica. (a) negro y blanco sobre banda horizontal: 2, 3, 4, 6, 7; (b) negro, blanco y rojo (7.5R 4/6): 5; (c) decoración de disposición vertical, convergente, de color negro sobre blanco fugitivo: 1. Procedencia: Saguara 2.

Unrestricted pottery types: flat bowls with geometric decoration. (a) black and white on a horizontal strip: 2, 3, 4, 6, 7; (b) black, white, and red (7.5 R 4/6): 5; (c) decoration with vertical and converging disposition, of fugitive black on white color: 1. Provenience: Saguara 2. 

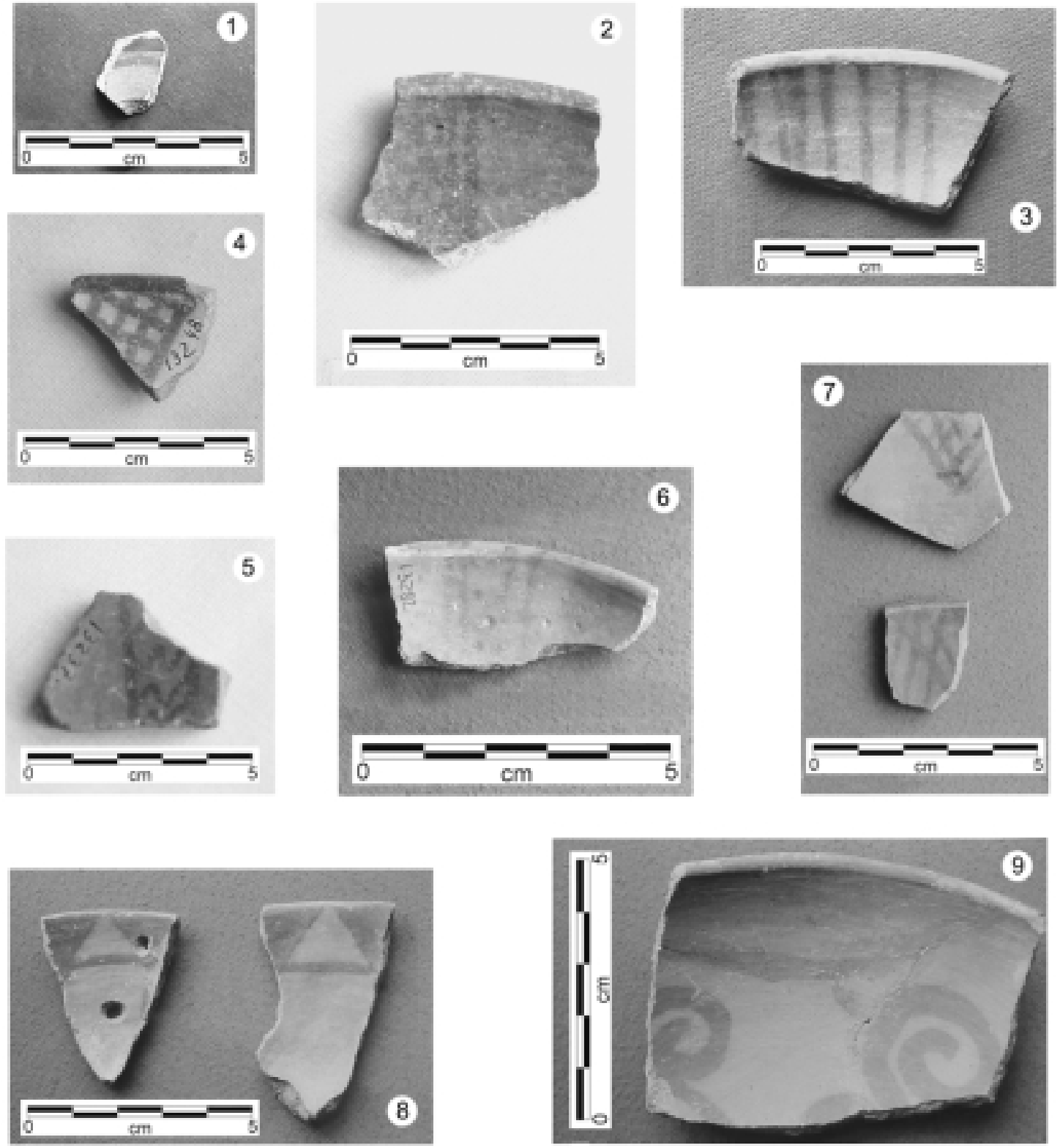

Figura 11. Ceramios no Restrictos. Escudillas con decoración geométrica monocroma de color negro de disposición horizontal o vertical. (a) sobre engobe de color rojo (10R 5/6): 1-7, 9; (b) sin engobe con superficie natural café rojiza (2.5YR 5/4): 8 . Procedencia: Saguara 2.

Unrestricted pottery types. Bowl with geometric monochrome decoration of vertical and horizontal black lines. (a) on red slip (10R 5/6): 1-7, 9; (b) on plain red without slip (2.5YR 5/4): 8. Provenience: Saguara 2.

(b.3) Jarros. Conformado por fragmentos de jarros de tamaño mediano a pequeño de decoración policromada. Está representado por (a) piezas botelliformes realizadas mediante moldes, con cuerpo de segmento de ovoide y base plana de 60 mm de diámetro, cuello cilíndrico y asa vertical en el cuello que semejan a la forma D de Rowe (1944); un espécimen es de cuello muy angosto y borde ligeramente evertido (Figura 8: 5). La superficie es bruñida recubierta con engobe rojo y decorada con campos verticales en negro y blanco o bandas paralelas diagonales de colores alternados (Figura 14: 4 y 5); (b) grupo heterogéneo de fragmentos de cuerpo de jarros, de superficie bruñida y deco- 

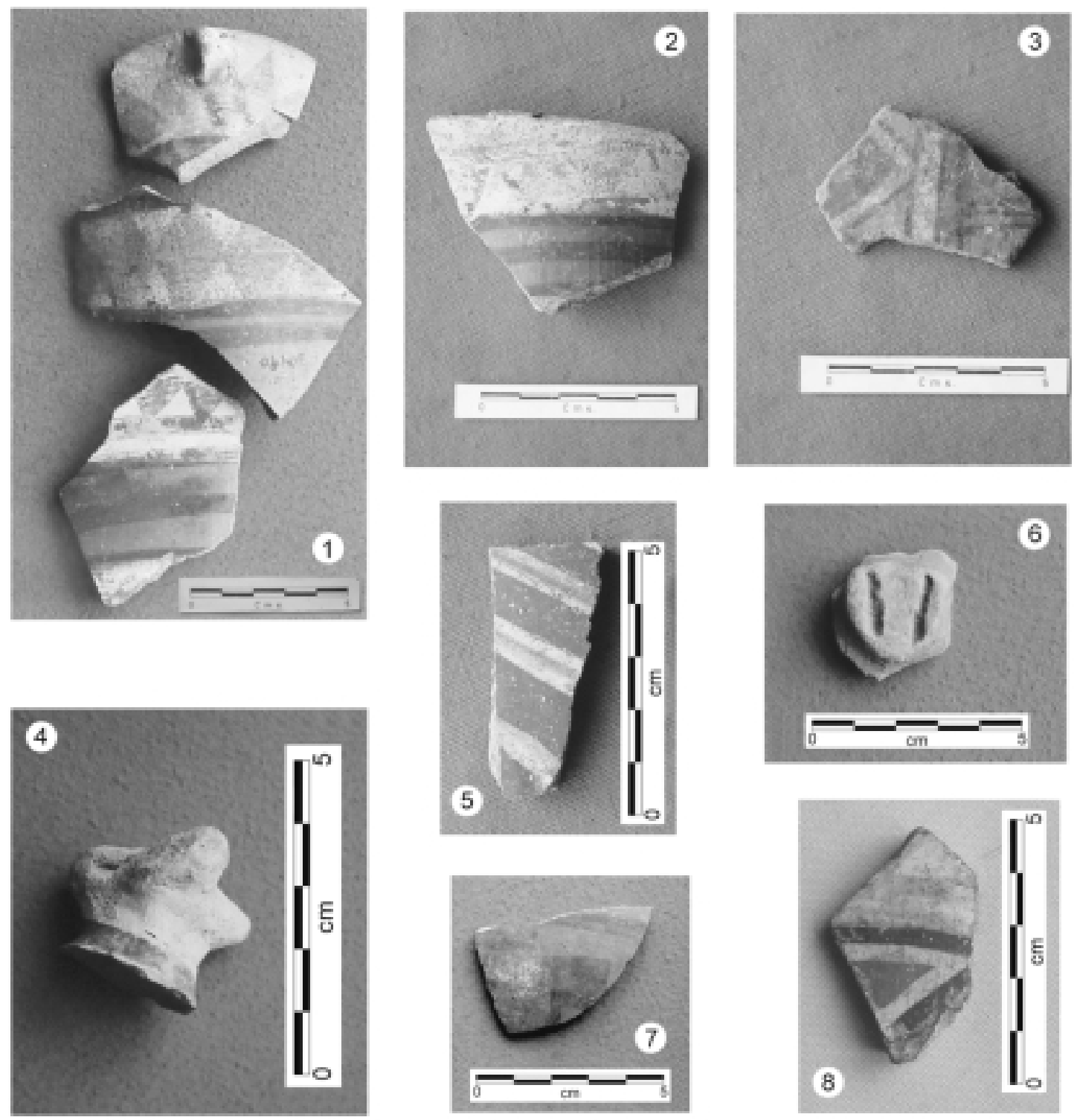

Figura 12. Ceramios Restrictos Complejos. Aríbalos. (a) decoración en el cuello de bandas horizontales con hileras de rombos negro y blanco sobre engobe rojo (7.5R 3-4/6): 1 y 2; (b) decoración en el cuerpo: negro y blanco sobre engobe rojo pálido (7.5R 6/6): 3 ; (c) motivo ajedrezado negro sobre engobe rojo (7.5R 4/4): 7; (d) bandas y líneas paralelas negro, blanco y rojo (5R 5/6): 5; (e) negro, blanco y rosado (5YR 7/2) sobre engobe rojo (7.5R 5/6): 8; (f) protúberos con cabeza de llamo y de felino: 4 y 6. Procedencia: Saguara 2, excepto 3 y 5 de Saguara 1.

Complex Restricted Pottery Types. "Aryballus". (a) neck decoration of horizontal strips with bands of rhomboids, black and white on red slip (7.5R 3-4/6): 1 y 2; (b) body decoration: black and white on light red slip (7.5R 6/6): 3; (c) chekerboard motive, black on red slip (7.5R 4/4): 7; (d) strip and parallel lines black, white and red (5R 5/6): 5; (e) black, white and pink (5YR 7/2) on red slip (7.5R 5/6): 8; (f) protuberances with llama and feline heads: 4 y 6. Provenience: Saguara 2, with the exception of 3 and 5 from Saguara 1.

ración geométrica de motivos complejos en rojo, blanco, anaranjado y amarillo, entre los cuales se reconoce el motivo del "cat spot" (Julien 1982) o bien utilizando los colores negro y rojo 10R 4/4 sobre amarillo rojizo (5YR 6/6) (Figura 14: 1-3, 8); (c) otro grupo presenta decoración geométrica de líneas o bandas de color negro horizontales, diagonales o entrecruzadas de color negro sobre superficie engobada de tonalidades de color rojo, o de hileras de volutas sobre superficie natural pulida (Figura 13: 1-4); (d) por último hay otro fragmento de jarro, no ilustrado, de superficie exterior pulida con engobe rojo pálido (7.5R 5/6) y decoración lineal horizontal y diagonal que produce cam- 

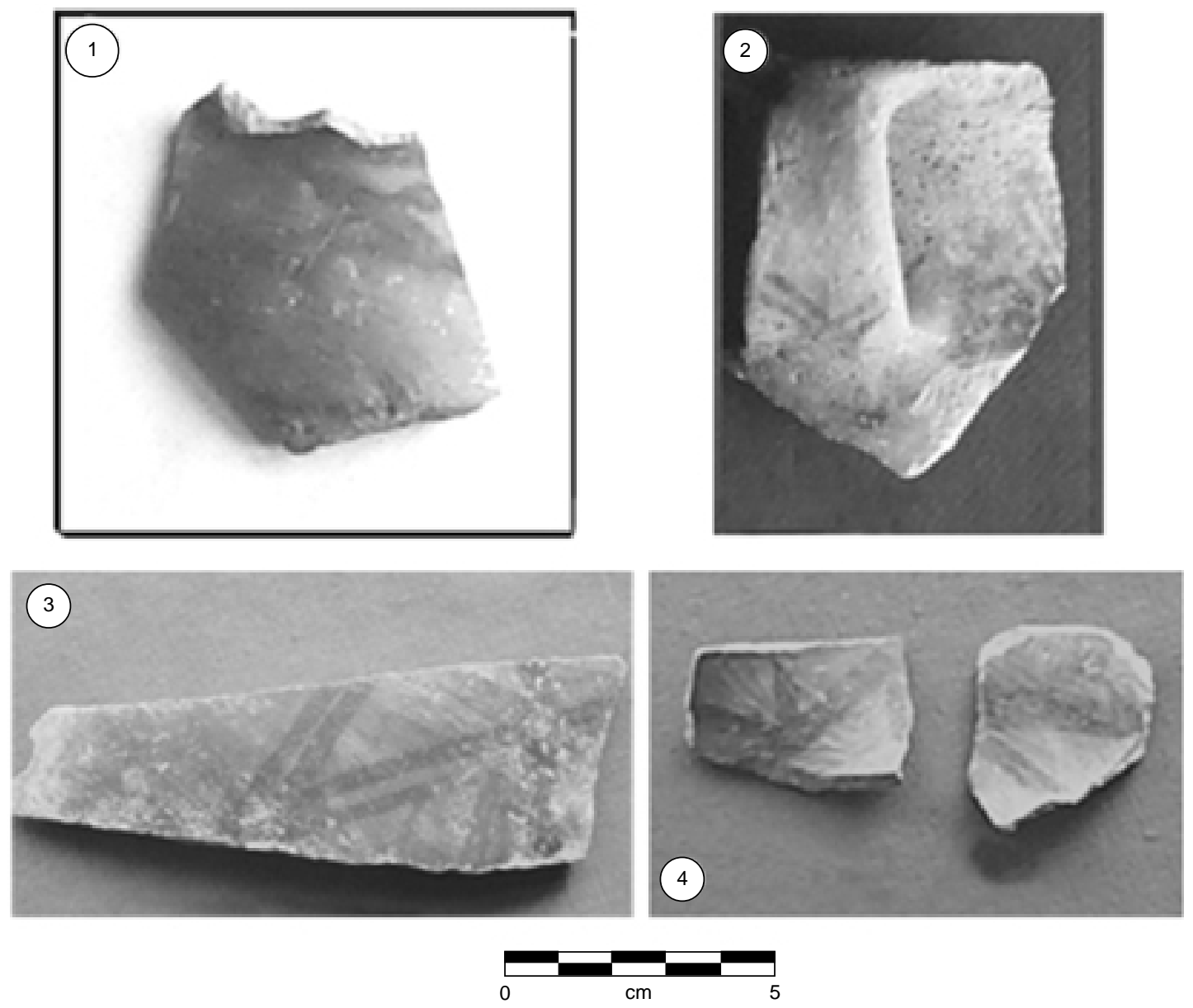

Figura 13. Ceramios Restrictos Complejos. Jarros y Cántaros, con decoración geométrica de bandas rectilíneas horizontales y diagonales, líneas entrecruzadas u onduladas y de pequeñas volutas de color negro. (a) sobre superficies con engobe rojo (7.5R 5/6): 2; (b) rojo (5R 5/3-4): 3 y 4; (c) Superficie pulida natural de rojo grisáceo (10R 5/3): 1. Procedencia: Saguara 1, excepto 1 de Saguara 2.

Complex Restricted Pottery Types. Jar and Globular Jar with geometric decoration of strips of criss-crossing horizontal and diagonal straight lines, crossing over or undulated lines, and small black spiral lines. (a) over red slip (7.5R 5/6): 2; (b) red (SR 5/3-4): 2; (c) red burnished surface (10R 5/3): 1. Provenience: Saguara 1, except 1 from Saguara 2.

pos triangulares rellenos con volutas o círculos concéntricos. Semeja a una jarrita del estilo Inca Palmira definido por Dauelsberg, que proviene del sitio homónimo o Az 76 del valle de Azapa, que está en depósito en el museo de San Miguel de Azapa.

(b.4) Ollas. Son de boca ancha y cuerpo achatado, base plana y asas ecuatoriales, semejantes al tipo F de Rowe (1944). Llevan en el cuerpo sobre el engobe de color rojo la aplicación de una serpiente modelada de cuerpo ondulado de color blanco con manchas de color rojo oscuro o, en su reemplazo, un asa horizontal de cuerpo lleno o también el modelado de la cabeza de un felino. Todas estas formas y estilos decorativos descritos se duplican en el yacimiento inca vecino de Pachica, indicando una estrecha correlación entre ambos sitios (Schiappacasse y Niemeyer 1998).

(c) Otros estilos adicionales de ceramios decorados

(c.1) Estilo Baño Rojo sobre alisado natural. De la colecta de superficie y excavaciones de Saguara 3 y del recinto 16 de Saguara 2, se individualizaron 

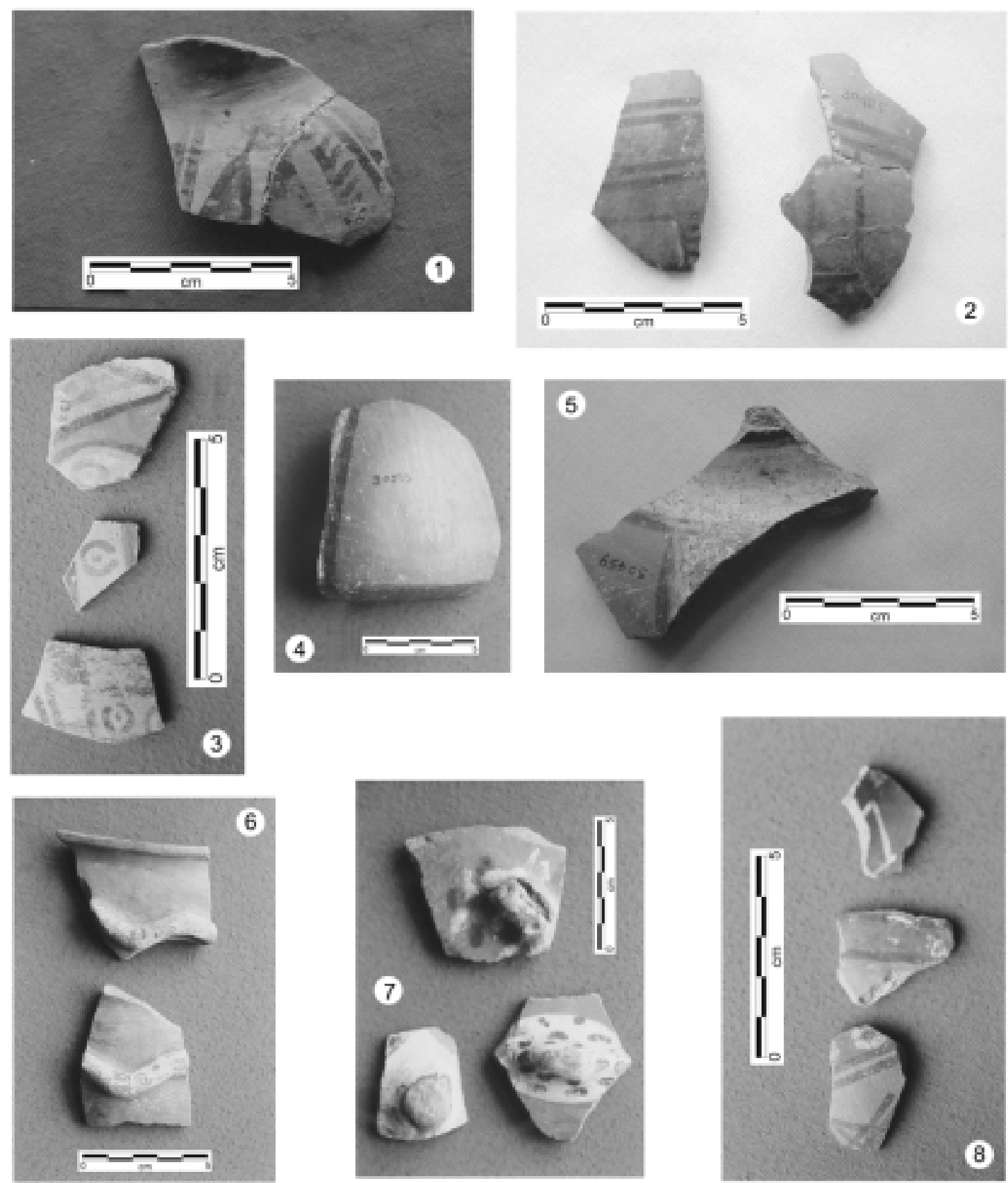

Figura 14. Ceramios Restrictos Complejos. Jarros, Botella y Ollas, agrupados de acuerdo al tratamiento de la superficie. (a) jarros policromos de superficie bruñida: 2, 3, 4; (b) decoración negro y rojo (10R 4/4) sobre amarillo rojizo (5YR 6/6): 1; (c) negro y rojo oscuro (5R 4/6) sobre rojo anaranjado (10R 5/6): 2 y 8 , donde se agrega el color blanco: 5; (d) negro y colores rojo oscuro (5R 4/6) y rojo (10R 5/6) sobre blanco rosado (7.5YR 8/2): 3; (e) cuerpo de botella bruñida con colores negro y blanco sobre engobe rojo (10R 5/6): 4; (f) ollas con sobre relieve de un ofidio de color blanco sobre superficie natural café rojiza (2.5YR 5/6): 6; (g) con representación de un felino en negro y blanco amarillento (10YR 8/6) sobre engobe rojo (10R 8/3): 7. Procedencia: Saguara 2, excepto 1 de Saguara 1.

Complex Restricted Pottery Types. Jar, Bottle, and Cooking Pots, grouped by surface treatment. (a) polished polychrome jar: 2, 3, 4;(b) black on red (10R 4/4), on reddish yellow (5YR 6/6): 1; (c) on black and dark red (5R 4/6), on orange red (10R 5/6): 2 and 8, with addition of white color: 5; (d) black and dark red colors (5R 4/6) and red (10R 5/6) on pinkish white (7.5YR 8/2): 3; (e) bottle shape with polished surface with black and white on red slip (10R 5/6): 4; (f) cooking pots with a snake-like over relief of white color on plain reddish brown surface (2.5YR 5/6): 6; $(g)$ with a feline representation on black and yellowish white (10YR 8/6) on red slip (10R 8/3): 7. Provenience: Saguara 2, with the exception of 1 from Saguara 1. 
fragmentos de ceramios de cuerpo globular y de cuello corto inflexionado de superficie interior y exterior alisada de color rojo grisáceo (5YR 6/5-4) semejante al de la pasta, de cocción oxidante con núcleo gris central de 7 a $10 \mathrm{~mm}$ de grosor. En la superficie exterior presentan bandas o manchas de un baño rojo escarlata diluido (7.5R 6-5/4-2). La pasta es de estructura granular con cavidades e inclusiones angulares de 0.5 a $2 \mathrm{~mm}$ predominantemente de cuarzo, además de feldespatos y escasa mica (Figura 14: 1, 3, 4). Estas características son compatibles con la cerámica Charcollo descrita originalmente por Dauelsberg (1959) en la sierra de Arica y distribuida en los cementerios con sepulturas de cistas aéreas y subterráneas de Charcollo y Alto de Chilpe, y en los asentamientos Tambo de Zapahuira y los Pucaras de Copaquilla y de Lupica, todos situados en la sierra de Huaylillas. Dauelsberg (1959) la describe como una cerámica tosca de superficie apenas alisada y de ornamentación escasa que se limita a líneas y puntos rojos, con formas semiglobulares y pasta con inclusiones de arena, de cocción en atmósfera oxidante. Inicialmente la situó en el Período Tardío, pero en una revisión posterior de la cronología de la cerámica de Arica (Dauelsberg 1960) la incluyó en el Horizonte Tricolor del Sur como el representante ceramológico de la sierra y contemporánea de los estilos Maitas, Chiribaya y Loreto Viejo del valle. Con posterioridad ha sido identificada en el litoral de Arica, en el sitio La Capilla 4, con fecha C14 de $700 \pm 100$ d.C. asociada a cerámica Maitas (Muñoz 1982) y también en el valle de Azapa, en los sitios Az 3 y Az 103, asociada a cerámica Cabuza y Tiwanaku, con cuatro fechas de TL de: $720 \pm 100$, $830 \pm 90,830 \pm 100$ y $850 \pm 90$ años d.C. Uribe $(1995,1999)$, Ayala y Uribe (1996) hacen un distingo entre la cerámica Charcollo-Azapa que sería más temprana y la cerámica Charcollo-Pica propia de la región de Tarapacá, de data tardía. De Camarones disponemos de una fecha de TL de $1.240 \pm 90$ años d.C. (UCTL 108) para un fragmento de escudilla Charcollo decorada con un motivo en " 8 " que proviene de Cuya, en el valle (Schiappacasse y Niemeyer 1988). En fecha más reciente Romero, Santoro y colaboradores caracterizan esta cerámica como propia de las poblaciones serranas que interactuaban con comunidades de valle y del altiplano durante el Período Intermedio Tardío; proporcionan una fecha de TL dentro de un rango de 1.395-1.460 años d.C. con 1
DS, contemporánea a fechados del estilo San Miguel (Romero 1999; Santoro et al. 2000). La cerámica Charcollo-Azapa es de formas predominantes abiertas, de tazones y keros, algunas de superficies bruñidas; hay una escudilla globular de cuello corto inflexionado que sería semejante a la de Saguara. Parece evidente que con el término Charcollo se han designado varias expresiones de una tradición cerámica de larga evolución temporal y espacial que ameritan su estudio comparativo.

(c.2) Estilos de la Cultura Arica. De la colecta de superficie de Saguara 3B y 4 y de la excavación de los recintos 3 y 4 de Saguara 2, se obtuvieron cuatro fragmentos de formas restrictas pertenecientes a estilos de la Cultura Arica; dos de ellos poseen decoración de líneas paralelas con hilera de triángulos de color negro sobre un fondo pulido sin engobe de color amarillo rojizo (7.5R 7/4) compatibles con el estilo Pocoma; el resto es de superficie bruñida con motivos rectilíneos y circulares complejos con colores blanco y rojo (7.5R 4/4) sobre un fondo engobado (2YR 5/4) asimilable al estilo Gentilar.

\section{Cerámica colonial}

La alfarería atribuible al período hispano está representada principalmente por fragmentos de alfares realizados a torno, algunos grandes y gruesos de 18 a $20 \mathrm{~mm}$, pertenecientes a formas restrictas complejas compatibles con grandes tinajas. De pasta compacta de cocción oxidante y con superficie exterior alisada recubierta a veces por un engobe delgado blanquecino amarillento o verdoso. Menos frecuentes son las formas irrestrictas representadas por fuentes abiertas algunas con asas verticales en el cuerpo compatibles con la Forma 3 , descrita para el sitio vecino de Pachica; por platos torneados de superficie vidriada policromada o con superficie pulida sin engobe, decorada por guirnaldas de color negro en los bordes, ambos se corresponden con la Forma 13 de Pachica, yacimiento en el cual, curiosamente, los restos de tinajas son excepcionales (Schiappacasse y Niemeyer 1998). Esta cerámica colonial está distribuida ampliamente en las muestras de superficie de los sectores de Saguara 1 y 2, y en algunas cuadrículas excavadas de los recintos 16, 17, 31 de Saguara 2, en especial del recinto 34 , donde hay una evidente 
reocupación colonial del sector norte del recinto como se consignó al describirlo.

La distribución según el tamaño de los fragmentos de cerámica de las excavaciones resultó ser bastante similar a la distribución de la fragmentación obtenida de las colectas de superficie, lo que indicaría que ambas muestras corresponden a depósitos secundarios, posiblemente fruto del pisoteo. En la Figura 15 puede observarse la similitud de las curvas de distribución de la fragmentación cerámica de la colecta de superficie de los recintos 17 y 34 de Saguara 2, comparada con las curvas de la fragmentación obtenida de la excavación de los mismos recintos. Pese a no haber realizado una búsqueda exhaustiva, no fue infrecuente el hallazgo en cuadrículas adyacentes de fragmentos pertenecientes a un mismo alfar.

La frecuencia relativa de los diferentes grupos cerámicos individualizados se calculó según el peso de la fragmentación, con promedios de 800 a 950 g por cuadrícula de los recintos excavados. Habíamos observado, con anterioridad, que no se producían diferencias significativas con las frecuencias calculadas según la cantidad de fragmentos, exceptuando los gruesos fragmentos de tinajas coloniales por su mayor peso relativo. Comparando la distribución porcentual de la cerámica decorada y no decorada producto de la colecta de superficie de los diferentes sectores de Saguara, se observó una alta frecuencia de cerámica decorada en los sectores 1 y 2 de Saguara que alcanza un $70 \%$ y $51 \%$ respectivamente, mientras que se invierte su popularidad respecto a la cerámica no decorada en los sectores 3 , 4 y 5 disminuyendo a un $16 \%$. Esta distribución selectiva se hace mas evidente si se comparan las frecuencias relativas de la fragmentación cerámica producto de las excavaciones entre los diferentes tipos de recintos del sector de Saguara 2 con los sectores 3 y 4 (Figura 16).

\section{Discos de cerámica}

Son especímenes discoidales obtenidos de fragmentos de vasijas cuyo contorno puede ser irregular o estar bien pulimentado, con diámetros variables entre 3 a $7 \mathrm{~cm}$. Dos de los discos de contorno regular presentan perforación bicónica central de 8 a $10 \mathrm{~mm}$, correspondiendo a pesas de torteros; los discos restantes podrían ser preformas, no pudiendo descartarse la posibilidad de que los discos de contornos tallados correspondan a piezas de un juego (Rydén 1947). De 19 especímenes, la mayoría (84\%) pertenecen al sector Saguara 2 y el 3\% remanente a Saguara 3.

\section{Metalurgia}

(a) Hachas. Dos especímenes de bronce poseen las características de hacha tipo T. Ambas tienen una base ancha de sección rectangular pero difieren en la forma de la hoja, en un espécimen es más larga que ancha y se expande moderadamente hacia el extremo del filo, mientras que el otro, es de hoja ancha y más corta con extremo distal expandido de forma semilunar (espécimen 1: longitud 119 $\mathrm{mm}$, base: ancho $80 \mathrm{~mm}$, espesor 14; extremo distal: ancho $56 \mathrm{~mm}$, grosor $4 \mathrm{~mm}$; espécimen 2: longitud $96 \mathrm{~mm}$, base: ancho $90 \mathrm{~mm}$, espesor $10 \mathrm{~mm}$; extremo distal: ancho $132 \mathrm{~mm}$ y grosor 3 $\mathrm{mm})$. El espécimen 1 proviene de la excavación de la cuadrícula G del recinto 15 de Saguara 2, y el otro, de la limpieza del silo 1 de Saguara 1 (Figura 17: 1 y 3). De la localidad vecina de Pachica poseemos el fragmento del extremo distal de un hacha cuyas características y dimensiones son idénticas a las del primer espécimen, las que posiblemente fueron obtenidas del mismo molde (Schiappacasse y Niemeyer 1998).

(b) Cuchillo o tumi. De mango angosto y extremo distal expandido con filo de contorno curvilíneo; presenta un doblez de $13 \mathrm{~mm}$ en el extremo del mango. Mide $84 \mathrm{~mm}$ de longitud y $86 \mathrm{~mm}$ de ancho y un grosor máximo de $3 \mathrm{~mm}$. Proviene de la excavación del recinto 34 de Saguara 2 (Figura 18: 3).

(c) Cincel o azuela. De forma subrectangular moderadamente expandida en el extremo distal del filo de contorno incurvado. Mide $124 \mathrm{~mm}$ de longitud con ancho de la base de $30 \mathrm{~mm}$ y $48 \mathrm{~mm}$ en el extremo distal; el grosor es de $5 \mathrm{~mm}$, adelgazándose a $2 \mathrm{~mm}$ en el filo, el cual está deformado posiblemente por uso. Proviene de la excavación de la cuadrícula noroeste del recinto 17 de Saguara 2 (Figura 17: 2).

(d) Aguja. De $116 \mathrm{~mm}$ de longitud, quebrada en el sitio de la perforación del extremo proximal con sección cilíndrica de $3 \mathrm{~mm}$ de diámetro. Proviene de la excavación del recinto 4 de Saguara 2 (Figura 18: 7). 


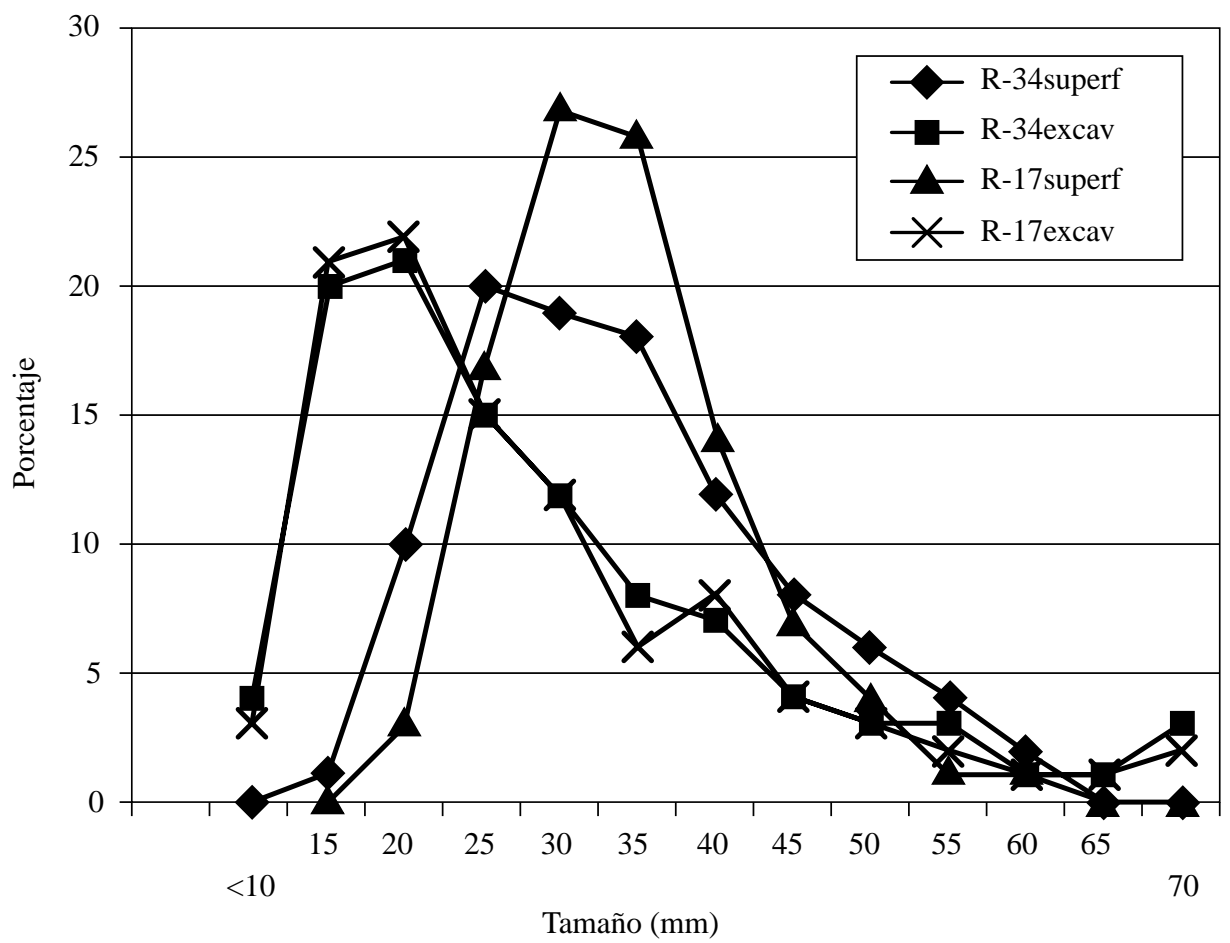

Figura 15. Variación porcentual del tamaño de la fragmentación cerámica: de superficie y de excavación de los Recintos 17 y 34 de Saguara 2.

Size variation of pottery fragments from surface and excavated samples, structures 17 and 34, from Saguara 2.

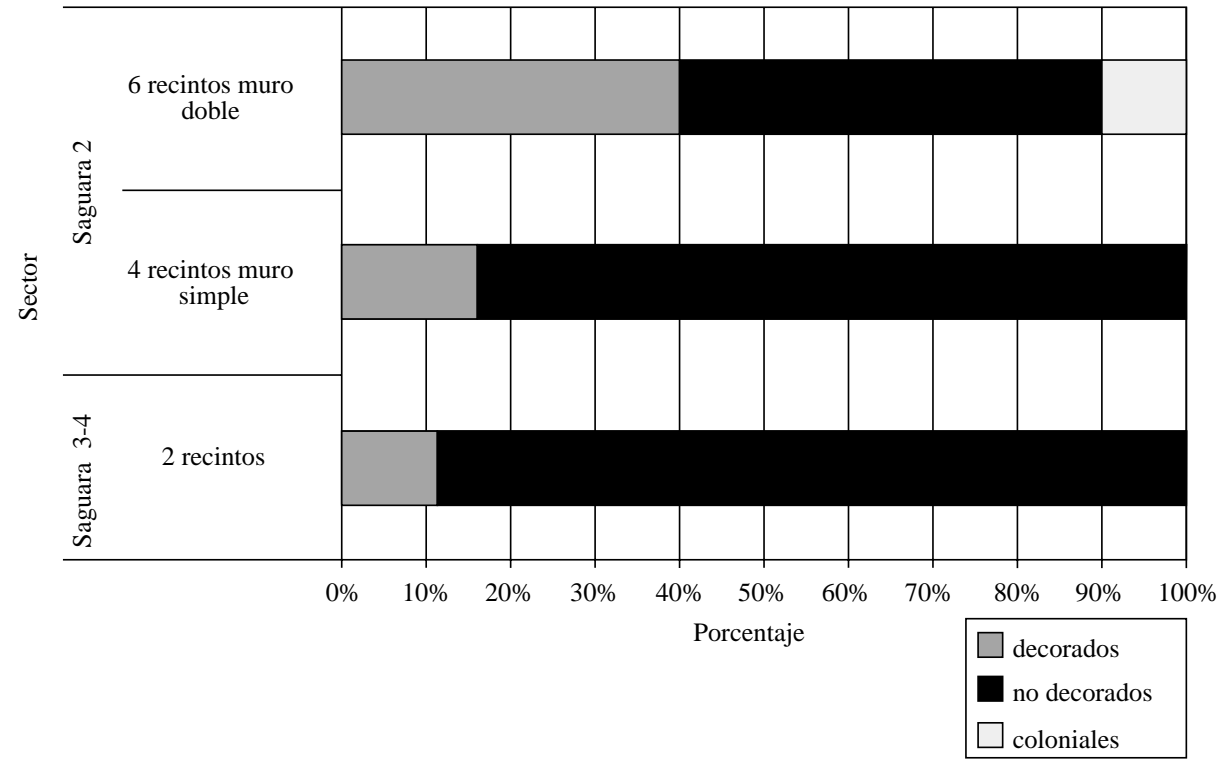

Figura 16. Proporción relativa de la cerámica Decorada y No Decorada. Recintos de muro doble y de muro simple de Saguara 2 y Recintos de Saguara 3 y 4.

Relative proportion of decorated and undecorated pottery. Structures with double and single walls from Saguara 2 and Saguara 3 y 4. 


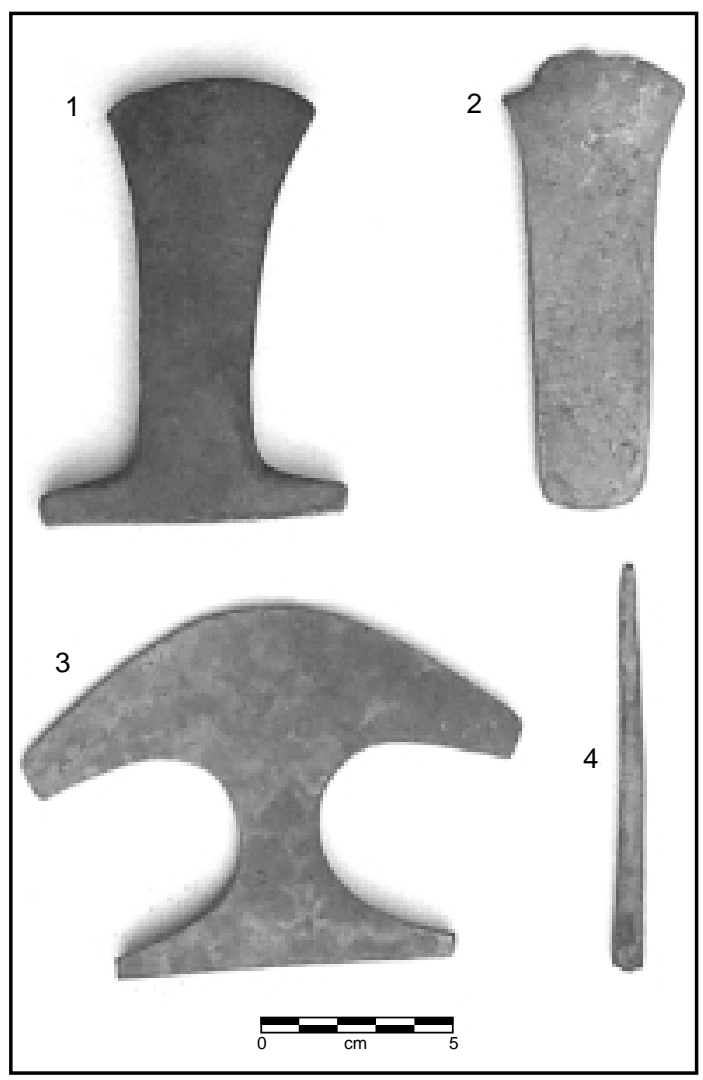

Figura 17. Metalurgia. (a) hachas T: 1 y 3; (b) cincel o azuela: 2; (c) varilla o punzón: 4. Procedencia: Saguara 2; excepto 2 de Saguara 1.

Metallurgy. (a) T axes: 1 and 3; (b) chisel or hoe blade: 2; (c) pointed rod: 4; Provenience: Saguara 2, with the exception of 2 from Saguara 1.

(e) Punzón o varilla. De $108 \mathrm{~mm}$ de longitud, con un extremo aguzado y el otro quebrado; es de sección cuadrangular de 8 x $9 \mathrm{~mm}$. Proviene de la colecta de superficie en el sector del ushnu de Saguara 2 (Figura 17: 4).

(f) Posible alfiler. De $41 \mathrm{~mm}$ de longitud y $3 \mathrm{~mm}$ de sección cilíndrica un extremo es aguzado y el otro expandido y doblado; proviene de la cuadrícula C del recinto 34 de Saguara 2 (Figura 18: 2).

(g) Cascabel o campanilla. Constituido por la mitad hemisférica de un cascabel de $18 \mathrm{~mm}$ de diámetro premunida de dos perforaciones opuestas cerca del borde; proviene de la excavación de la cuadrícula noroeste del recinto 17 de Saguara 2 (Figura 18: 6). Latcham (1938) describe un espé- cimen semejante, de $29 \mathrm{~mm}$ de diámetro, proveniente de Arica e inventariado en el Museo Nacional de Historia Natural.

(h) Objeto ornamental. Consistente en una estrella de seis puntas de 13 x $14 \mathrm{~mm}$ y $1 \mathrm{~mm}$ de espesor; proviene de la colecta de superficie del recinto 15 de Saguara 2 (Figura 18: 11).

(i) Pendiente o lauraque. Objeto alargado de 56 $\mathrm{mm}$ de longitud perforado en su extremo proximal que representa una cabeza humana con señalización de las facciones de la cara de nariz alargada y premunida de un adorno cefálico que recuerda la cornamenta de un macho cabrío. El extremo distal se adelgaza y expande a semejanza de la cola de un pez, no estando representadas las extremidades inferiores. El cuerpo está adornado por incisiones verticales en su cara ventral e incisiones lineales entrecruzadas en el dorso; no presenta rasgos que permitan determinar su sexo (Figura 18: 10 y Figura 19). Proviene de la excavación del recinto 4 de Saguara 2.

Estos adornos de aspecto antropomorfo son reconocidos con el nombre de lauraques por los chipayas de carangas, según Posnansky (1924, 1958), debido a su similitud con una entidad de aspecto de sirena de su folklore conocida como Lauracu. Los obtienen de la excavación de tumbas antiguas y las mujeres los llevan en la actualidad colgados de sus trenzas como distintivo de mujer casada. Varían en sus detalles pero como común denominador poseen un extremo cefálico antropomorfo y el otro distal que pudiera semejar la cola de un pez. Cuando llevan atributos sexuales la mayoría son femeninas. Posnansky $(1924,1958)$ ha homologado el adorno cefálico que llevan con frecuencia a la cornamenta de un borrego caprino. Se encuentran estos colgantes distribuidos ampliamente en el territorio meridional de la cuenca del Titicaca abarcando hasta los valles costeros. Cronológicamente está documentada su presencia en yacimientos del período Tardío. En territorios pacajes han sido descritos por Rydén (1947) en el sitio multicomponente de Wancani; asociados a cerámica inca pacaje en la localidad arqueológica de Calacoto por Portugal (1989); Pärssinen y Siiriainen (1994) también anotan su presencia en la Chullpa de Caquiaviri en territorio carangas. Para los valles Occidentales se conocen cuatro ejempla- 

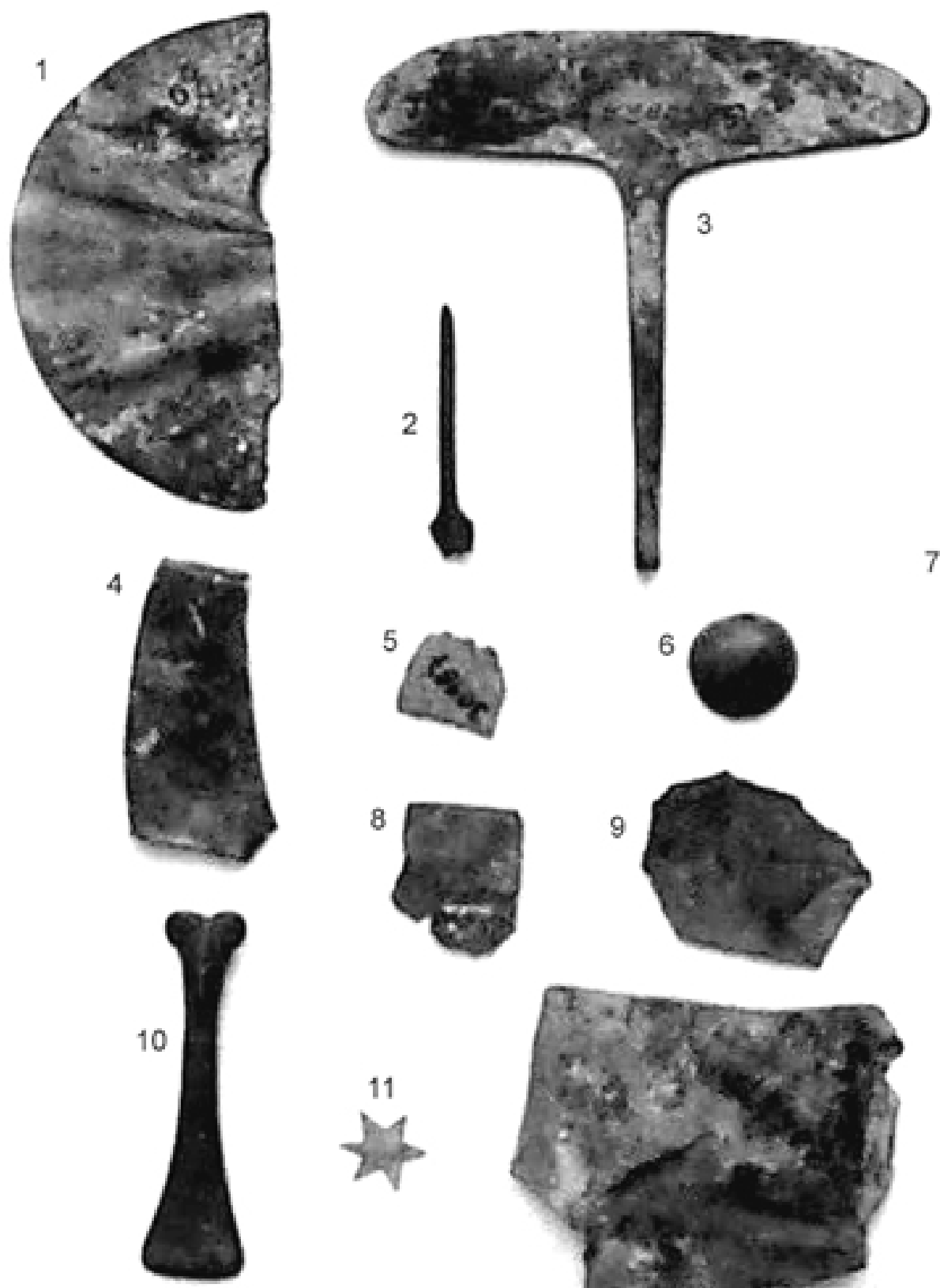

6

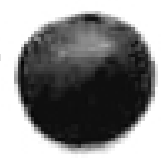

8
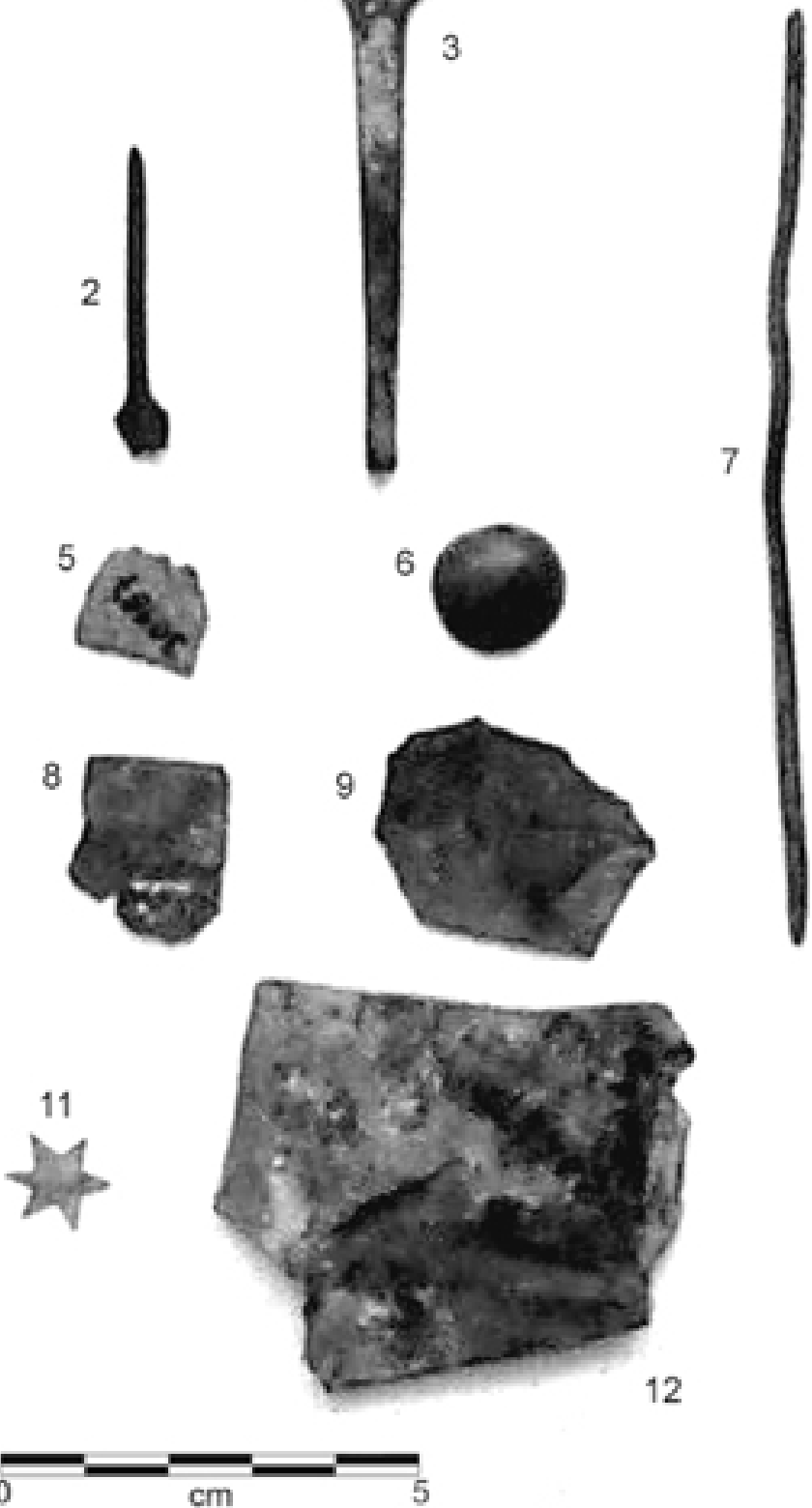

12

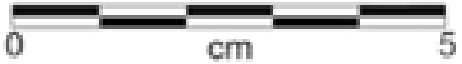

Figura 18. Metalurgia: (a) placa discoidal: 1; (b) alfiler: 2; (c) cuchillo o tumi: 3; (d) cascabel: 6; (e) aguja: 7; (f) adorno o lauraque: 10; (g) adorno en forma de estrella: 11; (h) fragmentos de láminas: 5, 8, 9 y 12. Procedencia: Saguara 2 excepto 1 y 2 de Saguara 1. Metallurgy: (a) discoidal plate: 1; (b) pin: 2; (c) knife or tumi: 3; (d) rattle: 6; (e) needle: 7; $(f)$ adornment or lauraque: 10; $(g)$ starshaped adornment: 11; (h) fragments of copper sheet: 5, 8, 9, 12. Provenience: Saguara 2, with the exception of one and two from Saguara 1. 


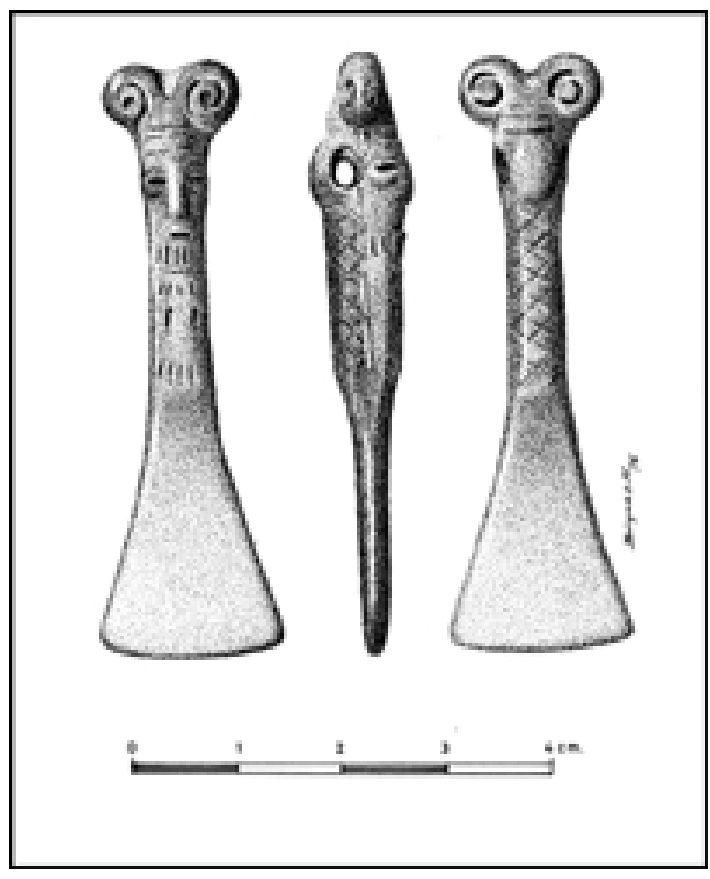

Figura 19. Metalurgia. Adorno o lauraque. Procedencia Saguara 2 , recinto 3 .

Metallurgy. Adornment or lauraque. Provenience Saguara 2, structure 3.

res, provenientes del sitio Playa Miller 6 del litoral de Arica, depositados en el Museo San Miguel de Azapa. Además existen referencias, no documentadas, de lauraques provenientes del cementerio inca Camarones 9 en la desembocadura de la quebrada homónima y del sitio Molle Pampa en el valle de Lluta (Guillermo Focacci comunicación personal).

(j) Placa discoidal. Corresponde a un fragmento equivalente a la mitad de una placa discoidal de $76 \mathrm{~mm}$ de diámetro y $0.8 \mathrm{~mm}$ de espesor. Proviene de colecta de superficie general de Saguara 1 (Figura 18: 1).

(k) Fragmentos de láminas. Se dispone de siete especímenes de placas delgadas de 1 a $0.5 \mathrm{~mm}$ de espesor, de forma irregular y tamaños variables no mayores de $60 \mathrm{~mm}$. Provienen de la colecta superficie general de Saguara 1; colecta de superficie de los recintos 4, 5, 6 y 14 de Saguara 2; excavación de los recintos 17 y 35 de Saguara 2 (Figura 18: 5, $8,9,12)$.
Considerando la proveniencia de los artefactos de metal, de un total de 18 especímenes: 15 pertenecen al sector de Saguara 2 y los 3 restantes a Saguara 1, estando ausentes en los sectores de Saguara 3, 4 y 5. En Saguara 2, el 56\% de estos objetos de metal corresponden a los recintos con cimientos de muro doble y el $27 \%$ a los de muro simple; el $17 \%$ restante proviene del sector de Saguara 1. Es de notar que hay dos recintos rectangulares con muros dobles con dos especímenes cada uno, y otro con tres, recintos que además concentran los artefactos más elaborados con excepción del adorno colgante o lauraque que corresponde al recinto 3 de muro simple. Como puede verse en la Figura 20, los objetos de metal se distribuyen inversamente a las hojas líticas de azadón en los diferentes sectores de Saguara.

\section{Lítica}

\section{Artefactos líticos tallados}

(a) Hojas de azadón o chila. Constituyen los artefactos líticos más frecuentes del yacimiento. Como se ha señalado anteriormente, fueron elaboradas in situ aprovechando la piedra laja de andesita de los farellones situados al norte del conjunto de estructuras que constituyen el sector Saguara 3. Estos especímenes en general son de forma oblonga más estrechos hacia el extremo del mango, lograda por tallado marginal bifacial de todo el contorno; el extremo distal que constituye el filo útil es de contorno redondeado y en un buen número de especímenes está pulimentado por el uso. Su tamaño es variable, con ejemplares enteros de 120 a 200 $\mathrm{mm}$ de longitud, pero hay especímenes fragmentados que sugieren longitudes mayores. El ancho máximo situado en el tercio distal varía de 70 a 90 $\mathrm{mm}$ con promedio de $80 \mathrm{~mm}$ y el grosor 8 a 20 $\mathrm{mm}$ con $13 \mathrm{~mm}$ de promedio. De un total contabilizado de 71 especímenes el 59\% pertenece a los sectores arqueológicos de Saguara 3, 4 y 5. El 28\% corresponde al sector de Saguara 2, pero con una clara distinción sectorial, en efecto el $20 \%$ proviene del sector situado hacia el extremo oriente del sitio compuesto por los recintos de muro simple mientras que solamente el $8 \%$ corresponde a los recintos con cimientos de doble muro. Por último, el $13 \%$ restante es del sector Saguara 1. Se hace evidente entonces una distribución diferenciada de estos implementos, concentrándose más de la mi- 


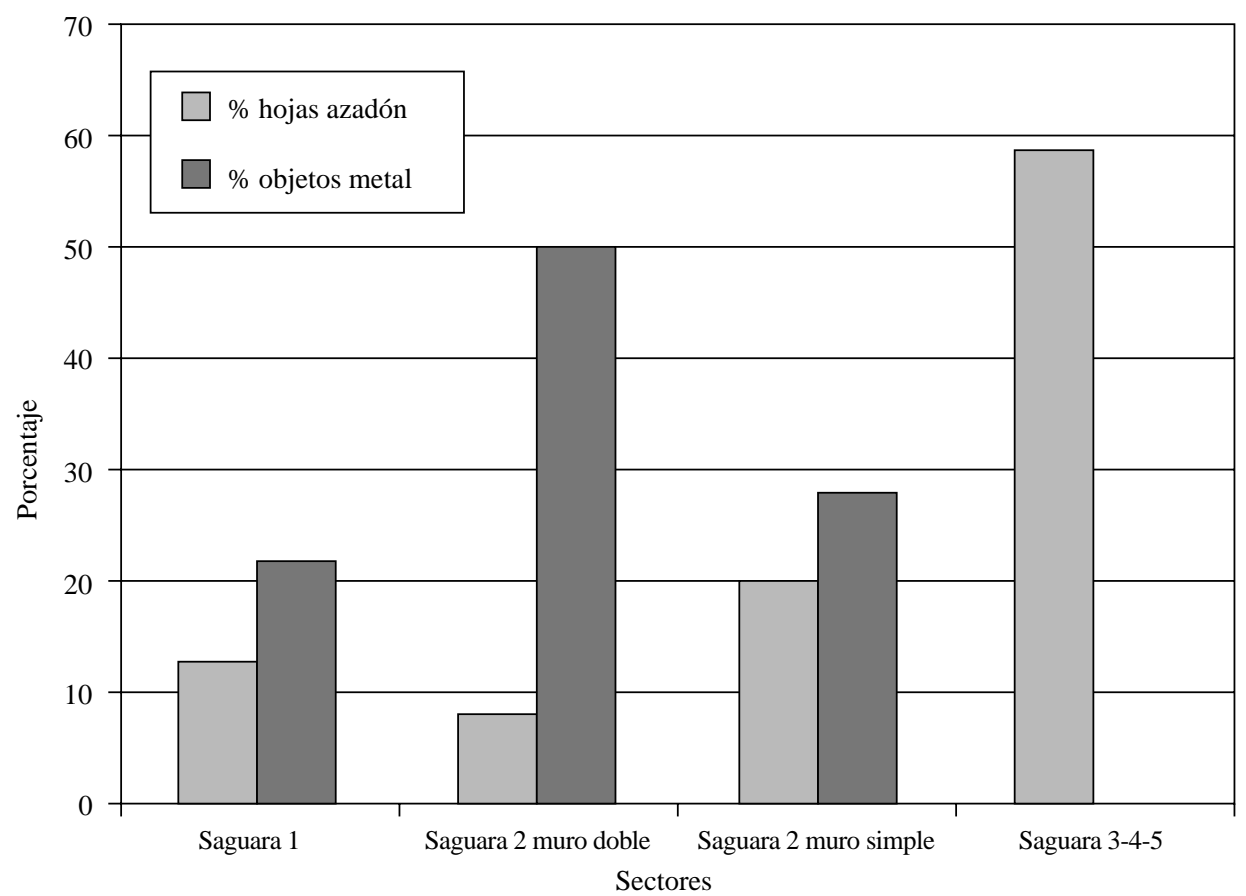

Figura 20. Proporción relativa de hojas de azadón y objetos metálicos en los diferentes sectores y tipo de recintos de Saguara.

Relative proportion of hoe blades and metallic objects from different sectors and types of structures from Saguara.

tad de ellos en los sectores de Saguara 3, 4 y 5 (Figuras 20 y 21).

La conformación de estas hojas es diferente a las que ilustra Latcham (1938: 125, Fig. 34), para la región atacameña. En la excavación del Sitio Cxa W-E1 del sector bajo de la quebrada de Camarones obtuvimos un espécimen semejante en la forma y tamaño (Niemeyer y Schiappacasse 1963).

(b) Puntas de proyectil. Constituyen el segundo lugar en frecuencia del material lítico tallado; son de calcedonia y se dispone de 11 especímenes terminados completos o fragmentados, además de algunas posibles preformas. La mayoría, exceptuando un ejemplar del recinto 15 de Saguara 2, proviene de la colecta de superficie de Saguara 1 y 2 , por lo que no puede precisarse su contexto. La variedad más frecuente está constituida por seis ejemplares de puntas pedunculadas de limbo triangular y pedúnculo convergente. Los especímenes restantes corresponden a la variedad apedunculada triangular de base adelgazada ligeramente cóncava y otra de limbo lanceolado. Los especímenes completos miden entre 25 a $35 \mathrm{~mm}$ de longitud. (c) Raspadores. Se registran dos raspadores laterales en basalto, planos convexos con retoque marginal unifacial del filo y otros dos raspadores de extremo, discoidales, de dorso alto plano convexo y retoque marginal unifacial del sector del borde útil; miden entre 35 a $60 \mathrm{~mm}$ de diámetro máximo basal. Exceptuando un espécimen de la excavación del recinto 15 de Saguara 2, el resto proviene de la colecta de superficie de Saguara 2.

(d) Martillo o percutor. Artefacto de talla bifacial de forma ovoidea, de basalto oscuro percutido en un extremo, de aproximadamente $200 \mathrm{~g}$, pertenece al recinto 11 de Saguara 1.

\section{Artefactos líticos pulimentados}

(a) Pesas de boleadora o ayullo. Hay 3 litos esféricos de hematita similares entre sí, compatibles con pesas de boleadoras; miden $50 \mathrm{~mm}$ de diámetro y su peso varía entre 200 y $240 \mathrm{~g}$; provienen de la excavación de los recintos 3 y 17 de Saguara 2 y de la superficie de Saguara 1. 


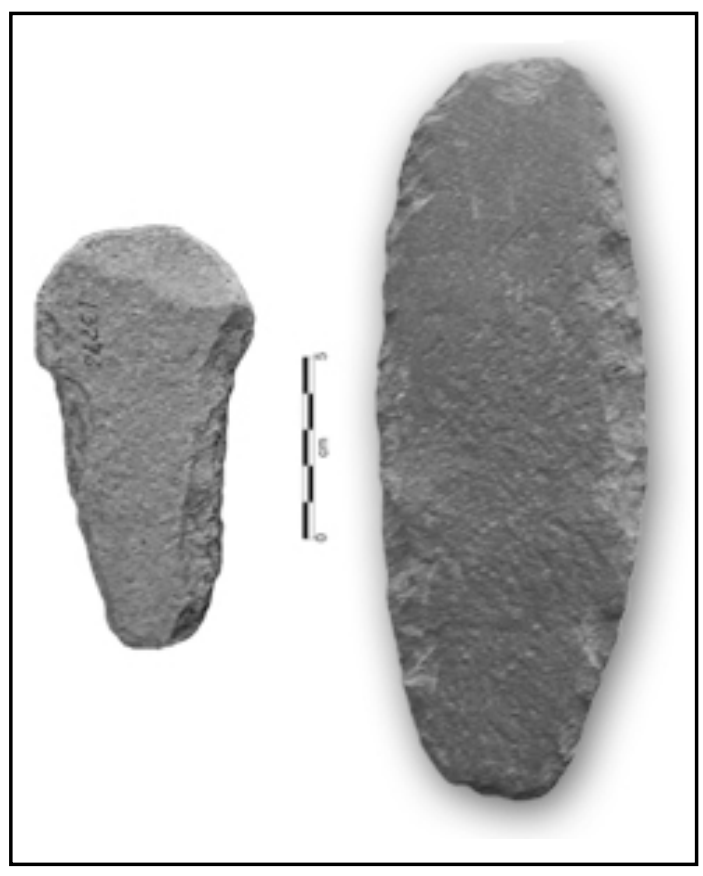

Figura 21. Lítica. Variación de tamaño de hojas de azadón. Procedencia: Saguara 3.

Lithics. Size variation of hoe blades. Provenience: Saguara 3.

(b) Piedras molino. Los molinos corresponden a bloques o piedras tabulares de granito con una cara aplanada de superficie pulimentada por efecto del desgaste por el uso, de aproximadamente $30 \mathrm{~cm}$ en su diámetro mayor. Con sus correspondientes piedras mano, pesan entre 500 y $600 \mathrm{~g}$, semejantes a las actualmente en uso en el poblado vecino de Esquiña para moler maíz. Además del molino poshispánico del recinto 34 , hay otros 3 especímenes de los recintos 4, 5 y 22 también de Saguara 2.

(c) Morteros. Hay 3 especímenes, dos de ellos quebrados, de forma subcuadrangular de 20 a 30 $\mathrm{cm}$ de diámetro mayor con excavación central de 3 a $4 \mathrm{~cm}$ de profundidad; provienen de la excavación de los recintos 16 y 34 de Saguara 2 y de Saguara 3B.

\section{Discusión}

La administración del estado inca estaba basada en provincias autosuficientes económicamente, pero dependientes de una planificación centralizada basada en los censos y en una superestructura ritual destinada a legitimar el poder central que, con la ayuda de la coerción, permitía al estado, al clero y a las panacas de los linajes incas obtener su renta movilizando la energía del trabajo comunitario. Los asentamientos provinciales estaban vertebrados por la red vial (Rowe 1947; Murra 1975b). La funcionalidad de estos asentamientos puede investigarse analizando su emplazamiento en el paisaje, su organización o planificación y características arquitectónicas, además de la diversidad cultural del depósito arqueológico y la naturaleza de los recursos locales.

El asentamiento de Saguara junto a la localidad vecina de Pachica deberían constituir nodos serranos en la red vial que desde Codpa y los Altos de Chocaya por el norte se dirige hacia el sur a Nama y Camiña (Vila Vila) y que, en sentido oriente a poniente, desde el altiplano de Oruro, por Paquisa, Chilcaya, Taruguire y desciende hacia el litoral de Caleta Camarones, pasando por los asentamientos de Huancarane Bajo, Hacienda Camarones Norte, Chuquibamba y posiblemente Cuya.

Llama la atención la cercanía entre los establecimientos de Saguara y Pachica, a diferencia de las distancias que separan el resto de los nudos viales. En el caso de Pachica, pese a las evidencias aportadas por un rico registro artefactual, la reocupación colonial ha obliterado sus características arquitectónicas, lo que ha limitado una mayor comprensión del rol que desempeñaba dentro del sistema de asentamiento. En Saguara, por el contrario, los asentamientos posteriores solamente han comprometido una parte menor de las evidencias arqueológicas, lo que ha permitido un análisis en mayor profundidad y esbozar una hipótesis de la razón de ser de dicho establecimiento inca. La sistematización de los vestigios arqueológicos individualizados en el yacimiento de Saguara, considerados junto a los recursos de su entorno, a las características arquitectónicas y al depósito arqueológico, permiten considerarlo no como un asentamiento con fines económicos ni de apoyo al sistema vial, rol que correspondería a la localidad vecina de Pachica, sino más bien destinado a una función más especializada, ceremonial, en el sistema de asentamiento organizado por la administración inca en este sector provincial.

El ceremonial en las provincias era una actividad de gran importancia para los incas porque por su intermedio se realizaban procesos redistributivos y de reciprocidad con las elites locales otorgándo- 
les bienes de prestigio, como un mecanismo de compensación por la pérdida del dominio económico sobre los recursos locales y del poder político. De esta forma se aseguraba su lealtad y legitimaba el dominio impuesto. Sobre la base de las evidencias expuestas, proponemos la siguiente interpretación del sitio de Saguara. El sector individualizado como Saguara 2, localizado en la explanada, centro del asentamiento, conformado por una plataforma escalonada y un conjunto de recintos aislados con rasgos arquitectónicos incas, reúne una serie de elementos que permiten atribuirle un significado ceremonial. Los recintos no ofrecen las características de las viviendas incaicas o wasi ni revelan presencia de fogones u otras evidencias de actividades domésticas. Por el contrario, la presencia de bienes de prestigio de metal y la abundancia de cerámica decorada representada principalmente por aríbalos, escudillas y platos hace presumir su ocupación esporádica en actividades de índole ceremonial. Es sabido que la mayoría de estos acontecimientos eran acompañados por cantos, además de abundantes libaciones: "comenzaron a beber de la chicha que allí tenían y que tenían mucha.." (Juan de Betanzos [1551-1557] citado por Niles 1995).

La plataforma escalonada la hemos homologado a la estructura denominada $u s h n u$, estructura que se localiza a menudo en la porción central o a un costado de la plaza de algunos asentamientos incas. Debemos a Hyslop (1990) una revisión completa de los antecedentes etnohistóricos y arqueológicos de este elemento arquitectónico. De acuerdo a este autor, sus antecedentes deberían remontarse a un conjunto arquitectónico que existía en el Cuzco, consistente de una plataforma con un asiento elevado, una escalinata orientada hacia el este y una depresión premunida de una canaleta de drenaje. En ella se realizaban, según señalan las crónicas, ceremonias en honor al Sol, con sacrificios de llamos, quemas de textiles y derrame de chicha en la depresión. Según Hyslop (1990), no se habrían identificado estructuras semejantes en el resto del territorio propiamente cuzqueño y, por lo tanto, debería corresponder a un rasgo propio de determinados asentamientos incas provinciales, destinados posiblemente a diversas actividades ceremoniales, político administrativas y religiosas. En los centros provinciales de mayor importancia esta estructura puede llegar a ser muy imponente y compleja en su diseño, como, por ejemplo, la "fortale- za" de Wilka Wamán en la plaza de Cajamarca, conformada por cinco plataformas escalonadas en el interior de un recinto amurallado, además de una kallanka (Gasparini y Margolies 1980). Hacia la frontera meridional del imperio, específicamente en la región del noroeste trasandino donde aparece con bastante frecuencia, esta estructura se simplifica y reduce de tamaño, como ocurre en los sitios de Shincal, Potrero de Payogasta, Tambería del Inca en Chilecito, Punta de Balasto y Chaquiago, por nombrar algunos ejemplos (Raffino 1981; Williams y D'Altroy 1998). En nuestro territorio, además de la plataforma de Saguara, se conoce la del sitio Viña del Cerro en Copiapó, ambas con una escalera orientada al este y localizadas en una explanada o plaza (Castillo 1998). La plataforma situada en un promontorio en el yacimiento de Cerro Verde, en la localidad de Caspana del Loa Superior, también representaría un ushnu, pero localizado fuera de una plaza (Castro 1992).

Algunas de estas estructuras, posiblemente las menos elaboradas, se erigieron ex profeso para determinados acontecimientos. Así es que, según Juan de Betanzos [1551-1557] (citado por Niles 1995) en ocasión de la inspección que el inca Huayna Cápac realizara a las provincias de Xaquixahuana y Andahuaylas, fue recibido por los gobernadores en un ushnu erigido especialmente para la ocasión en la plaza de la localidad, con festejos que incluyeron cantos, danzas y sacrificio de llamos y que el inca retribuyó con tejidos, mujeres y objetos de oro. Otra información, ahora de Joan Santa Cruz de Pachacuti Yamqui en los inicios del siglo XVII (citado por Niles 1995), refiere que durante el desplazamiento hacia el norte de la gran armada compuesta por varios escuadrones que Huayna Capac había organizado para la campaña de Quito, en localidades distantes cada 30 leguas $(130 \mathrm{~km}$ aproximadamente) se erigía un ushnu destinado a la inspección de la tropa. Sobre la base de estos antecedentes podría formularse la hipótesis de que los ushnu de elaboración relativamente sencilla de la región meridional andina, incluyendo los del Noroeste Argentino y este de Saguara podrían haber sido erigidos ex profeso para determinados acontecimientos. El acontecimiento más reciente y de mayor trascendencia ocurrido durante el período de los incas "históricos" parece haber sido la visita de cuatro años de duración que realizara Huayna Cápac al Collasuyu y que abarcó Tucumán 
y Chile. Visita cuyo objetivo principal era solicitar la contribución en tropa y abastecimientos de los caciques locales en preparación de la campaña contra las etnias del Ecuador que se habían rebelado contra su autoridad, hechos que habrían ocurrido durante los primeros decenios del siglo XVI (Niles 1995). Como hipótesis, pudiera plantearse que el asentamiento de Saguara pudo haber sido una de las localidades destinadas a recibir y proporcionar albergue a comitivas de personajes de alto rango, delegadas por el Inca, para visitar las localidades más periféricas del Collasuyu en busca de dichos pertrechos. Ocasiones que se habrían acompañado del ceremonial y festividades adecuadas con la participación de la población local y sus autoridades.

El sector marginal de Saguara 2, con recintos de muros sencillos de planta relativamente circular también, exhibe una alta proporción de cerámica ceremonial y de otros bienes de prestigio como por ejemplo el lauraque, adorno característico de poblaciones carangas y pacajes, por lo que suponemos evidenciaría la presencia de una comunidad altiplánica de mitimaes a cargo de la administración del asentamiento y control de la población local. Esta comunidad local, asentada en el sector de Saguara 3 y adyacentes, caracterizada por el tipo de vivienda, por la presencia de estilos alfareros locales y por la abundancia de implementos agrícolas, estaría prestando su fuerza de trabajo o corveé en el abastecimiento y servicio de la localidad, además de su propio sustento.

Por último, el sector de Saguara 1 comprendería, además de un conjunto residencial destinado como albergue de las comitivas visitantes, localizado en el mismo sector del poblado actual donde aún quedan restos de cimientos de muros dobles, un conjunto aislado de depósitos o collqas y un sector de enterramiento con sepulturas de cistas aéreas y subterráneas pertenecientes probablemente a la comunidad local, teniendo en consideración la presencia de cerámica Charcollo en sepulturas encistadas en el sitio cementerio Charcollo de la sierra de Arica (Dauelsberg 1959).

En relación con la procedencia de la cerámica inca de Pachica, en todo semejante a la de Saguara, habíamos propuesto (Schiappacasse y Niemeyer 1998) que ese conjunto de características bastante homogéneas, con algunas formas no propiamente incas como la escudilla, y otras de claro acervo inca, decoradas con motivos cuzqueños pero organizados en forma diferente a la de la cerámica del Cuzco, mostraba semejanzas con la producción alfarera del período inca de la cuenca del Titicaca (Tschopik 1946; Julien 1993). Esta relativa estandarización de producción alfarera se contrapone con la variabilidad de las pastas, tamaño de las vasijas, tratamiento de superficie y estilos decorativos, que caracterizan las diferentes "naciones" o agrupaciones políticas que integraban dicho territorio en tiempos anteriores al inca, características que indican ausencia de especialización y estandarización aun en el ámbito local: cada parcialidad habría dispuesto de poblados orientados hacia la elaboración de cerámica en escala acorde a una economía doméstica de tiempo parcial (Stanish 1997).

La administración inca debió planificar un aumento de la producción alfarera, haciéndose necesario modificar el modo de producción, con énfasis en la especialización y centralización artesanal, destinada a lograr una mayor eficiencia y control en la producción y distribución (Murra 1978; D’Altroy y Bishop 1990). Según Arnold (1994), además de los factores socioculturales debe tenerse presente el factor regulador del ambiente en la tecnología cerámica; las condiciones climáticas que caracterizan las tierras altoandinas, con una estación prolongada de alta humedad, con lluvias y baja insolación, actúan como limitantes ambientales que regulan la producción alfarera según las estaciones. Lograr un incremento de la producción anual obviando estas limitaciones requeriría disponer de amplias instalaciones indispensables para el secado y almacenamiento de las vasijas, facilidades que excedían los recursos disponibles por las unidades domésticas. Por tal motivo, debió ser necesario concentrar dicha producción en talleres especializados con una dotación permanente de artesanos bajo administración estatal. Se tiene conocimiento de un gran centro artesanal de esta naturaleza hupi o cupi en Millerea, en el lado septentrional del lago cerca de Huancané, sector omasuyu de la nación Colla, "ccop" significa ollero en aymara (Murra 1978). Este centro, además de los olleros, reunía también a tejedores y plumereros. Según los antecedentes disponibles esta factoría habría sido organizada por Huayna Cápac, quien estableció allí mitimaes a permanencia originarios exclusivamente de parcialidades collas junto a sus familias, a quienes proporcionó además chacras para el sustento 
(Espinoza Soriano 1987). Hay información de otro posible centro en Ayaviri situado en el sector norte del lago. En territorio lupaca está documentado que en tiempos del inca existían ayllos de copeolleros o cupi equivalentes a una pachaka tanto en las parcialidades hanan y hurin de las cabeceras de Chucuito y de Acora (Julien 1982). Los olleros lupacas preincas debieron ser artesanos de tiempo parcial que elaboraban cerámica decorada por encargo de la elite, considerando la distribución preferencial de dicha cerámica en los asentamientos principales (Stanish 1997), pero pudieran haber desarrollado una actividad independiente en la elaboración y distribución de la cerámica doméstica o utilitaria. Por el contrario, la administración inca debió establecer una tributación o corvée de tiempo completo desarrollada por los artesanos en sus lugares de residencia o en establecimientos especializados como el de Millerea (Costin y Hagstrum 1995). Es probable que también existiera una artesanía alfarera especializada en los territorios ocupados por pacajes y carangas aunque no se dispone de información de ello. Se conocen, sin embargo, por lo menos dos sitios incaicos más meridionales con evidencias de producción alfarera, gestados por mitmakunas: el yacimiento de Potrero-Chaquiago situado en la provincia de Catamarca del Noroeste Argentino (Lorandi 1983) y Tambillos en la provincia de Mendoza, en los límites de la expansión imperial hacia el sur (Bárcena 1992). Este gran volumen de alfarería estandarizada, pero con características propias de cada centro productor, debió servir de vehículo, con su iconografía emblemática, en la legitimación del dominio inca, siendo distribuida, como expresión de la "generosidad institucionalizada", selectivamente a los dignatarios y personal administrativo, a las elites locales y utilizada también en actividades ceremoniales patrocinadas por el estado con el concurso de las comunidades en todas las provincias del Collasuyu (Murra 1975b).

Agradecimientos: La investigación en terreno contó, en su oportunidad, con el apoyo de la ex sede de la Universidad del Norte en Arica y de la Junta de Adelanto de Arica.

\section{Referencias citadas}

Agurto Calvo, S.

1987 Estudio Acerca de la Construcción, Arquitectura y Planeamiento Incas. Cámara Peruana de la Construcción, Lima.

Albarracín, J.

1996 Tiwanaku: Arqueología Regional y Dinámica Segmentaria. Editorial Plural, La Paz.

Arnold, D

1994 La tecnología cerámica andina: una perspectiva etnoarqueológica. En Tecnología y Organización de la Producción de Cerámica Prehispana en los Andes, editado por L. Shimada, pp. 477-504. Universidad Católica del Perú, Lima.

Ayala, P. y M. Uribe

1996 Caracterización de dos tipos cerámicos ya definidos: Charcollo y Chiza Modelado. Boletín de la Sociedad Chilena de Arqueología 22: 24-28.

Bárcena, J.

1992 La ocupación incaica en Mendoza: El tambo de Tambillos. Gaceta Arqueológica Andina 21: 155-172.

Castillo, G.

1998 Los Períodos Intermedio Tardío y Tardío desde la Cultura Copiapó al Dominio Inca. En Culturas Prehistóricas de Copiapó, editado por H. Niemeyer, M. Cervellino y G. Castillo, pp. 163-282. Impresos Universitaria, Santiago.

Castro, V.

1992 Nuevos registros de la presencia incaica en la provincia de El Loa, Chile. Gaceta Arqueológica Andina 21: 139-154.
Costín, C. y M. Hagstrum

1995 Standardization, Labor Investment, Skill and the Organization of Ceramic Production in Late Prehistoric Highland Peru. American Antiquity 60: 619-639.

D’Altroy T. y R. Bishop

1990 The Provincial Organization of Inka Ceramic Production. American Antiquity 55: 120-137.

Dauelsberg, P.

1959 Cerámica del valle de Azapa. Boletín Museo Regional de Arica 3: 47-52.

Dauelsberg, P.

1960 Algunos problemas sobre la cerámica de Arica. Boletín Museo Regional de Arica 5: 94-108.

Dauelsberg, P.

1982 Investigaciones arqueológicas en la sierra de Arica, sector Belén. Chungara 11: 63-83.

Espinoza Soriano, W.

1987 Migraciones internas en el reino Colla. Tejedores, plumereros y alfareros del Estado Imperial Inca. Chungara 19: 243-289.

Gasparini, G. y L. Margolies

1980 Inca Architecture. Indiana University Press, Bloomington.

Hayashida, F.

1994 Producción cerámica en el imperio Inca: una visión global y nuevos datos. En: Tecnología y Organización de la Producción de Cerámica Prehispana en los Andes, editado por. I. Shimada, pp. 443- 475. Pontificia Universidad Católica del Perú, Lima. 
Hayashida, F.

1999 Style, Technology and State Production: Inka Pottery Manufacture in the Leche Valley. Latin American Antiquity 10: 337-352.

Hyslop, J.

1990 Inca Settlement Planning. University of Texas Press, Austin.

Julien, C.

1982 Inca decimal administration in the lake Titicaca region.

En The Inca and Aztec States 1400-1800, editado por G. Collier, R. Rosaldo y J. Wirth, pp. 119-151. Academic Press, New York.

1993 The Inca occupation of the province of Andamarca Lucanas, Peru. En Provincial Inca Archaeological and Ethnohistorical Assessment of the Impact of the Inca State, editado por M.A. Malpass, pp. 177-233. University of Iowa, Iowa City.

Latcham, R.

1938 Arqueología de la Región Atacameña. Prensas de la Universidad de Chile, Santiago.

Lorandi, A M.

1932 Olleros del Inca en Catamarca, Argentina. Gaceta Arqueológica Andina 2: 6-7.

Muñoz, I.

1982 La Capilla 4. Un asentamiento poblacional tardío en la costa de Arica. Documentos de Trabajo 2: 98-125. Universidad de Tarapacá, Arica.

Murra, J.

1975a Las investigaciones en etnohistoria andina y sus posibilidades en el futuro. En Formaciones Económicas y Políticas del Mundo Andino. Instituto de Estudios Peruanos, Lima.

Murra, J.

1975b En torno a la estructura política inca. En Formaciones Económicas y Políticas del Mundo Andino. Instituto de Estudios Peruanos, Lima.

Murra, J.

1978 Los Olleros del Inka: Hacia una Historia y Arqueología del Qollasuyu. En Historia, Problema y Promesa. Homenaje a Jorge Basadre, editado por F. Quezada, F. Pease y D. Sobrevilla, pp. 415-423. Pontificia Universidad Católica del Perú, Lima.

Niemeyer, H. y V. Schiappacasse

1963 Investigaciones arqueológicas en las terrazas de Conanoxa, valle de Camarones. Revista Universitaria 48. Anales de la Academia Chilena de Ciencias Naturales, Santiago.

Niemeyer, H.; V. Schiappacasse e I. Solimano

1971 Patrones de poblamiento de la quebrada de Camarones (Provincia de Tarapacá). Actas del VI Congreso de Arqueología Chilena: 115-137. Universidad de Chile, Santiago.

Niemeyer, H. y V. Schiappacasse

1988 Patrones de asentamiento incaicos en el norte grande de Chile. En Las Fronteras del Estado Inca, editado por T. Dillehay y P. Netherly, pp. 141-179. BAR International Series, Oxford.

Niles, S.

1995 The Shape of Inca History. University of Iowa Press, Iowa City.

Pärssinen, M. y A. Siiriainen

1994 Inca-Style Ceramic and their Chronology Relative to the Inca Expansion in the Southern Lake Titicaca (Bolivia). Latin American Antiquity 6: 255-272.

Portugal, M.

1988 Informe de la prospección a Pacajes. Arqueología Boliviana 3: 109-117.

Posnansky, A.

1924 Nuevas investigaciones en Carangas, Bolivia. XXI

Congrèss International des Américanistes: 95-102. Göteborg.

Posnansky, A.

1958 Tihuanacu. The Craddle of American Man. Editorial Don Bosco, La Paz.

Raffino, R.

1981 Los Inkas del Kollasuyu. Editorial Ramos Americana, La Plata.

Romero, A.

1999 Ocupación multiétnica en la sierra de Arica: Arquitectura, uso del espacio y distribución cerámica en el poblado arqueológico de Huaihuarani. Boletín-e AZETA. (http: // www.uta.cl/masma/azeta/huai_frs.html).

Rowe, J.

1944 An introduction to the archaeology of Cuzco. Papers of the Peabody Museum of American Archaeology and Ethnology $27 \mathrm{~N}^{\circ}$ 2. Cambridge, Massachusetts.

Rowe, J.

1963 Inca culture at the time of the Spanish conquest. En Handbook of South American Indians Volume 2, editado por J. Steward, pp. 183-330. Smithsonian Institution, Washington, D.C.

Rydén, $\mathrm{S}$.

1947 Archaeological Researches in the Highlands of Bolivia. Elanders Boktryckeri AB, Göteborg.

Santoro, C., A. Romero, V. Standen y A. Torres

2000 Continuidad y cambio en las comunidades locales, períodos Intermedio Tardío y Tardío, Valles Occidentales, Área Centro Sur Andina. Ponencia leída en el XV Congreso Nacional de Arqueología Chilena, Universidad de Tarapacá, Arica.

Schiappacasse, V., A. Román, I. Muñoz, A. Deza A. y G. Focacci 1998 Cronología por termoluminiscencia de la cerámica del extremo norte de Chile: Primera Parte. Actas del XI Congreso Nacional de Arqueología Chilena Tomo II: 43-60. Museo Nacional de Historia Natural, Santiago.

Schiappacasse, V. y H. Niemeyer

1988 Avances y sugerencias para el conocimiento de la prehistoria tardía de la desembocadura del valle de Camarones (Región Tarapacá). Chungara 22: 63-84.

Schiappacasse, V. y H. Niemeyer

1998 Continuidad y cambio cultural en el poblado actual, colonial e inca de Pachica, quebrada de Camarones. Chungara 29: 209-247.

Stanish, C.

1997 Nonmarket Imperialism in the Prehispanic Americas: The Inka Occupation of the Titicaca Basin. Latin American Antiquity 8: 195-216.

Stanish, C., C. De la Vega, L. Steadman, K.L. Frye, C. Justo, L. Onofre, M. Seddon, y P. Calisaya.

1997 Archaeological survey in the Juli-Desaguadero region of lake Titicaca basin, southern Perú. Fieldiana Anthropology New Series 2, Field Museum of Natural History. 
Tschopik, M.

1946 Some notes on the archaeology of the Department of Puno, Perú. Papers of the Peabody Museum of American Archaeology and Ethnology $27 \mathrm{~N}^{\circ} 3$. Harvard University, Crambridge.

Uribe, $\mathrm{M}$.

1995 Cerámica arqueológica de Arica (extremo norte de Chile). Primera etapa de una reevaluación tipológica. Ac- tas del XIII Congreso Nacional de Arqueología Chilena Tomo II: 81-96. Universidad de Antofagasta. Antofagasta. Uribe, $\mathrm{M}$.

1999 La cerámica de Arica 40 años después de Dauelsberg. Chungara 31: 189-228.

Williams, V. y T. D'Altroy

1998 El sur del Tawantinsuyu: Un dominio selectivamente intenso. Tawantinsuyu 5: 170-178.

\section{Nota}

1 Trabajo presentado en el XV Congreso Nacional de Arqueología Chilena, Universidad de Tarapacá, Arica 2000. 